Florida International University FIU Digital Commons

\title{
Interdependencies in Corporate Development: Relationship between Strategic Alliance and Acquisition Activities
}

\author{
Rimi Zakaria \\ rimi.zakaria@gmail.com
}

DOI: $10.25148 /$ etd.FI13042903

Follow this and additional works at: https://digitalcommons.fiu.edu/etd

Part of the Business Commons

\section{Recommended Citation}

Zakaria, Rimi, "Interdependencies in Corporate Development: Relationship between Strategic Alliance and Acquisition Activities" (2013). FIU Electronic Theses and Dissertations. 893.

https://digitalcommons.fiu.edu/etd/893 


\title{
FLORIDA INTERNATIONAL UNIVERSITY
}

Miami, Florida

\section{INTERDEPENDENCIES IN CORPORATE DEVELOPMENT: RELATIONSHIP BETWEEN STRATEGIC ALLIANCE AND ACQUISITION ACTIVITIES}

\author{
A dissertation submitted in partial fulfillment of \\ the requirements for the degree of \\ DOCTOR OF PHILOSOPHY \\ in \\ BUSINESS ADMINISTRATION
}

by

Rimi Zakaria 
To: Dean David Klock

College of Business Administration

This dissertation, written by Rimi Zakaria, and entitled Interdependencies in Corporate Development: Relationship between Strategic Alliance and Acquisition Activities, having been approved in respect to style and intellectual content, is referred to you for judgment.

We have read this dissertation and recommend that it be approved.

$\begin{array}{r}\hline \text { Nathan Hiller } \\ \hline \text { Isadore Newman } \\ \hline \text { William Schneper } \\ \hline \text { Sumit Kundu, Co-Major Professor } \\ \hline \text { William Newburry, Co-Major Professor }\end{array}$

Date of Defense: March 29, 2013

The thesis of Naomi Enzinna is approved.

$\begin{array}{r}\text { Dean David Klock } \\ \text { College of Business Administration } \\ \hline \begin{array}{r}\text { Dean Lakshmi N. Reddi } \\ \text { University Graduate School }\end{array}\end{array}$

Florida International University, 2013 
(C) Copyright 2013 by Rimi Zakaria

All rights reserved. 


\section{DEDICATION}

To my mother Bilquis Banu. I am thankful every day for your love and inspiration. 


\section{ACKNOWLEDGMENTS}

I have been fortunate to know some of the most knowledgeable, intellectually creative, and thoughtful people, who have, either directly or indirectly, played a role in my Ph.D. journey. I want to thank them all.

I especially acknowledge my advisor and co-chair Prof. Sumit Kundu. I am thankful for your guidance throughout my doctoral process, for your confidence in my abilities, and for your commitment to my development as an academic. To my advisor and co-chair Prof. William Newburry, thank you very much for your constructive comments on the dissertation, and for believing in the potential of my research. I am very appreciative of my external committee member Prof. Anu Phene. Your exceptional comments, suggestions, and several rounds of reviews have not only improved this dissertation but also greatly contributed to my growth as a researcher. Thanks to Prof. Newman for his resourcefulness and advice on the methodological rigor of this dissertation. Sincere thanks to Prof. William Schneper and Prof. Nathan Hiller, for your availability and encouragement. Beyond my dissertation committee members, I especially thank Prof. Galen Kroeck for his help throughout my Ph.D. process.

I acknowledge the funding and logistical support I received at various phases of my PhD from the College of Business, University Graduate School, Center for International Business Education and Research, Graduate Student Association, and Graduate Scholar and Professional Committee at Florida International University (FIU), the Academy of International Business, The University of Pennsylvania, and University of Wisconsin (Madison and Whitewater). Thanks to Maria Rodriguez for her help in managing the massive data set, and for some of the key statistical analyses. 
I also take this opportunity to thank some of my friends in particular. To Rifat Akhter, thank you for inspiring me to pursue a doctorate, and for always believing in my scholarly abilities. To Lei, for many thought-provoking conversations and, of course, for being such a wonderful friend. To Mayurakshi and Himadri, for all the fun-filled weekends, and for becoming my kith and kin in Miami. Many thanks to Beverly, Michelle, Nathalie, Stephanie, and Whitney for sharing with me their contagious optimism, which made the duration of the doctoral program seem rather short. None of these would have been possible without the love and support of my family. My endless gratitude to my mother Bilquis Banu for being one of the strongest women I have been fortunate to know and to follow. Thanks to my father Shamsher Zakaria, for always encouraging me to be independent. To my loving sisters Jhumi and Tami, thanks for your inspiration, friendship, and much more. To my aunt Hasina Banu, thank you for your unconditional affection.

All of you have helped me maintain a balance between my personal and professional life by offering so much: from homemade meals to intellectual insights. I am truly moved by each one of you. 


\title{
ABSTRACT OF THE DISSERTATION \\ INTERDEPENDENCIES IN CORPORATE DEVELOPMENT: RELATIONSHIP BETWEEN STRATEGIC ALLIANCE AND ACQUISITION ACTIVITIES
}

\author{
by \\ Rimi Zakaria \\ Florida International University, 2013 \\ Miami, Florida \\ Professor Sumit Kundu, Co-Major Professor \\ Professor William Newburry, Co-Major Professor
}

A substantial amount of work in the field of strategic management has attempted to explain the antecedents and outcomes of organizational learning. Though multinational corporations simultaneously engage in various types of tasks, activities, and strategies on a regular basis, the transfer of organizational learning in a multi-task context has largely remained underexplored in the literature. To inform our understanding in this area, this dissertation aimed at synthesizing findings from two parallel research streams of corporate development activities: strategic alliances and acquisitions. Structured in the form of two empirical studies, this dissertation examines: 1) the strategic outcomes of alliance experience of previously allying partners in terms of subsequent acquisition attempts, and 2) the performance implications of prior alliance experience for acquisitions. The first study draws on the relational view of inter-organizational governance to explain how various deal-specific and dyadic characteristics of a partnership relate to partnering firms' post-alliance acquisition attempts. This model theorizes on a variety of relational mechanisms to build a cohesive theory of inter- 
organizational exchanges in a multi-task setting where strategic alliances ultimately lead to a firm's decision to commit further resources. The second study applies organizational learning theory, and specifically examines whether frequency, recency, and relatedness of different dimensions of prior alliances, beyond the dyad-level experience, relate to an acquirer's superior post-acquisition performance. The hypotheses of the studies are tested using logistic and ordinary least square regressions, respectively. Results analyzed from a sample of cross-border alliance and acquisition deals attempted (for study I) and/or completed (for study II) during the period of 1991 to 2011 generally support the theory that relational exchange determines acquiring firms' post alliance acquisition behavior and that organizational routines and learning from prior alliances influence a future acquirer's financial performance. Overall, the empirical findings support our overarching theory of interdependency, and confirm the transfer effect of learning across these alternate, yet related corporate strategies of alliance and acquisition. 


\section{TABLE OF CONTENTS}

CHAPTER

PAGE

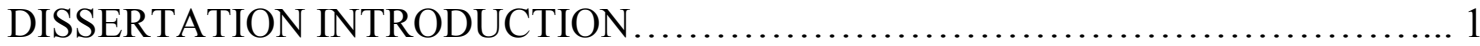

\section{STUDY I}

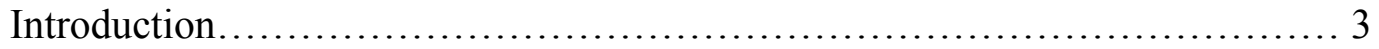

Theoretical Backdrop...................................................... 5

Hypotheses Development............................................... 10

Methodology ........................................................... 21

Results and Discussion................................................. 26

Limitations and Implications......................................... 30

Contribution............................................................ 31

\section{STUDY II}

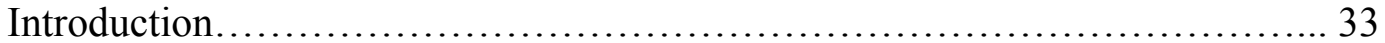

Theoretical Backdrop..................................................... 34

Hypotheses Development.................................................. 39

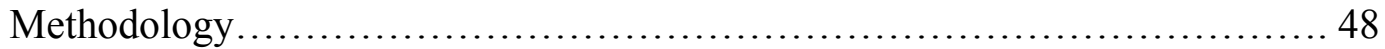

Results and Discussion................................................. 54

Limitations and Implications........................................... 58

Contribution............................................................. 59

DISSERTATION CONCLUSION ............................................. 61

\section{REFERENCES}

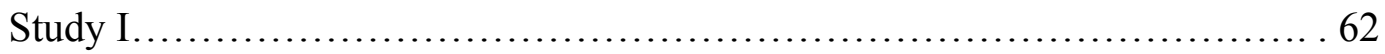

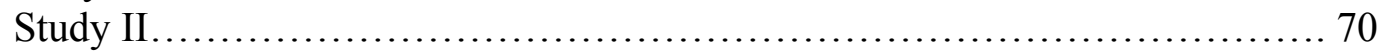

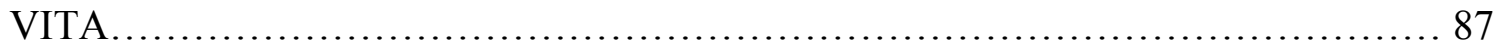




\section{LIST OF TABLES}

TABLE

PAGE

\section{STUDY I}

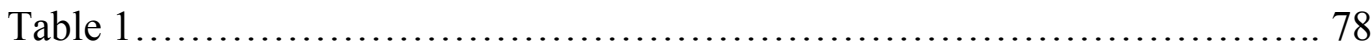

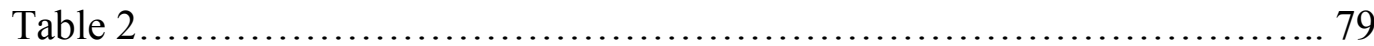

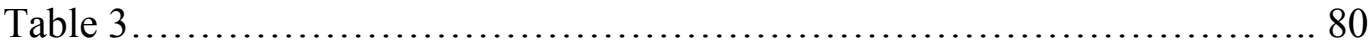

\section{STUDY II}

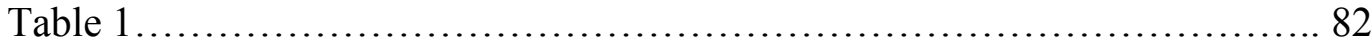

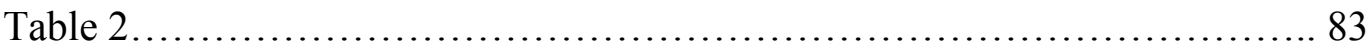

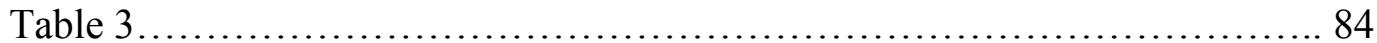




\section{INTERDEPENDENCIES IN CORPORATE DEVELOPMENT: RELATIONSHIP BETWEEN STRATEGIC ALLIANCE AND ACQUISITION ACTIVITIES}

\section{DISSERTATION INTRODUCTION}

Firms seeking to strategically combine their resources with those of other firms often follow two popular alternative governance structures: strategic alliances or acquisitions (Wang and Zajac, 2007). Decades of research by strategic management researchers suggest substantial degree of similarity in the factors of antecedents, processes, and outcomes in both alliance and acquisition activities. Numerous studies (Arend, 2004; Porrini; Wang and Zajac) expressed that these parallel firm activities are potentially interdependent. Despite this potential interdependence, until very recently, strategic management literature addressed alliance and acquisition activities as two discrete or parallel streams (Reur and Arino, 2007). Only a handful of very recent studies (Agarwal, Anand, Bercovitz, and Croson, 2012; Zaheer, Hernandez, and Banerjee, 2010) indicated that these two corporate development activities may have substantial overlap. In an endeavor to seek their inter-relationships, this dissertation takes an integrative approach and proposes the two empirical studies synthesizing both alliance and acquisition research.

Strategic alliances are arrangements between two or more independent firms that choose to carry out a project or to jointly manage in a specific business area by coordinating the necessary resources and capabilities rather than either operating independently or sharing their operations (Dussauge and Garrette, 1997; Dussauge, Garrette, and Mitchell, 2000). Whereas acquisition activities are those deals where a firm purchases a second firm - though the medium of exchange (e.g., cash, stock) and degree 
of ownership of this purchase may vary (e.g., buying a small equity, controlling share, majority share, full ownership). According to King, Dalton, Daily, and Covin (2004), the most general theoretical motivation for firms engaging in M\&A activity is the firms' pursuit of creating synergy (i.e., the notion that the sum of merging two firms is greater than their individual parts).

This dissertation is structured in terms of two empirical studies addressing two interrelated, yet distinct sets of hypotheses. The rest of this document therefore bifurcates into two standalone articles. Before we proceed to the articles, the following is an overarching framework that represents the research models of this dissertation (illustrated by Figure 1: Overarching Framework of the Dissertation): 


\section{STUDY I:}

\section{RELATIONSHIP BETWEEN DYADIC AND DEAL CHARACTERISTICS OF PARTNERSHIP AND POST-ALLIANCE ACQUISITION ATTEMPT}

\section{INTRODUCTION}

Although the competencies and learning processes relating alliance and merger \& acquisition (M\&A) activities are two well developed bodies of research in strategic management, the potential interdependencies of learning across these corporate activities have been underexplored (Zollo and Reuer, 2010; Zeira and Newburry, 1999; Newburry and Zeira, 1997). Arend (2004) expressed that alliances and M\&As can be considered related corporate activities and, therefore, are worthy of studying collectively. In fact, prior research suggests that a substantial number of strategic alliances go through postalliance governance adjustments and other dynamic changes (Reuer and Zollo, 2005; Reuer, Zillo, and Singh, 2002; Reuer and Zollo (2000), including ending in M\&A (Kogut, 1991; Bleeke and Ernst, 1993; Garette and Dussauge, 2000). The phenomenon of using alliances as a screening tactic for acquisitions is also documented in the literature (e.g., Balakrishnan and Koza, 1993; Nanda and Williamson, 1995). It is still largely under-explained as to what factors or mechanisms result in such a post-alliance M\&A attempt in an interfirm partnership. In an attempt to integrate these two bodies of research, we examine the underlying factors in strategic alliances that may explain a firm’s post-alliance M\&A strategy with an alliance partner. Drawing upon organizational learning theory (Nelson and Winter, 1982; Levitt and March, 1988) and the relational view (Dyer and Singh 1998 Lane and Lubatkin, 1998; Lorenzoni and Lipparini, 1999) of 
interfirm partnerships, the theoretical model of our study examines how organizational learning from prior partnering experience in alliance activities and other partnershipspecific factors (Gulati, 1999; Hayward, 2002; Haleblian and Finkelstein, 1999 and 2002; Haleblian, Kim, and Rajagopalan, 2006) associate with a focal firm's post-alliance strategy. More specifically, we seek to examine how deal-specific and dyadic factors of an alliance relate to a firm's future M\&A strategy.

Given that alliances and acquisitions involve two or more firms creating an interorganizational context of transactions, analyzing only focal-firm characteristics to understand this dyadic phenomenon provides us with a one-sided and incomplete view of a dyadic phenomenon (Zajac and Olsen, 1993). Taking individual firm characteristics makes us underestimate the relational aspects of two firms' preferences and interactions that are critical for determining the process of their resource combination (Zajac and Olsen, 1993). This narrow analysis is likely to be misleading or at least incomplete when our outcome variable may be a byproduct of the said partnership. Therefore, we are interested in exploring how endogenous factors to a dyadic relationship may relate to a focal firm's post-alliance strategic action to acquire a partner.

The rest of this paper is organized in the following sections. First, I review the literature on organizational learning and the relational view with particular focus on strategic alliance and M\&A activities. Second, I formulate a conceptual model and develop a wide range of hypotheses pertaining to dyadic and deal specific aspects to establish a relationship between an alliance agreement and a focal firm's potential M\&A attempt. Third, a research design is presented elaborating on the sample, variables, 
measures, and statistical techniques. The concluding section articulates some potential limitations, originality, and theoretical contributions of the study.

\section{THEORETICAL BACKDROP: STRATEGIC ALLIANCES AND ACQUISITIONS}

Partner selection in inter-firm alliance and target selection in acquisition contexts has been a well-established stream of research in strategic management. Numerous studies have studied the determinants of firms seeking to join partnerships and acquire other firms as two parallel research streams. However, in this study, we consider an interdependent model, where we focus on only those acquisition attempts where the acquiring and target firms had a prior alliance with each other, which likely influenced their decision to undertake an acquisition deal.

\section{Alliance Preceding Acquisition}

Prior work suggests that strategic alliances sometimes end in acquisitions (Kogut, 1991; Bleeke and Ernst, 1993; Garette and Dussauge, 2000). Consistent with these empirical findings, Haspeslagh and Jemison (1991: 247) noted that in many cases, collaboration serves as the first productive step toward understanding the environment, market, or industry before an acquisition. Bowman and Hurry (1993) have also suggested that firms can use prior alliances as intermediate strategic options to eventually acquire a partner. However, none of the above-mentioned studies examined which factors induce post-alliance acquisition attempts. Few theoretical arguments (besides very recent exceptions, e.g., Zollo and Reuer, 2010; Zaheer, Hernandez, and Banarjee, 2010) have been proposed to guide research on how relational characteristics of firm dyads interact to impact the partnering firms' post-alliance strategies in related corporate development 
activities. But, it is evident from the nature of alliance and acquisition deals that there seems to be a natural increase in commitment of firm resources from alliances (i.e., less resource intensive) to acquisitions (i.e., more resource intensive in terms of holding a majority share of equity). Therefore, we attempt to address these evocative gaps in the strategy literature by examining how firms' dyadic experience and exchange associate with their post-alliance acquisition attempts.

\section{Distinction between Alliance and Acquisition}

Broadly speaking, strategic alliances are arrangements between two or more independent firms that choose to carry out a project or operate in a specific business area by coordinating the necessary skills and resources jointly rather than either operating independently or sharing their operations (Dussauge and Garrette, 1997; Dussauge, Garrette, and Mitchell, 2000). Whereas acquisitions are those deals where a firm purchases a second firm, though the form (e.g., cash, stock) and degree of ownership (e.g., controlling share, majority share, full ownership) of such purchase may vary. According to King, Dalton, Daily, and Covin (2004), the most general theoretical motivation for firms engaging in M\&A activity is the firms' pursuit of creating synergy (i.e., the notion that the sum of merging two firms is greater than their individual parts).

Strategic alliances can take different forms: non-equity contractual alliances (CA), minority-equity alliances (EA), and joint ventures (JV), where the latter one involves establishing a formal legal entity. A JV or EA allows partners to share equity control, while in a non-equity $\mathrm{CA}$ the partners neither share equity control as in a minority-equity investment nor create a new organizational entity as is done in a JV. Furthermore, even in JVs that involve equity investment, the determinants of distribution of ownership among 
partners remain inconclusive (Cuypers and Martin, 2010). In a recent study, Phene and Tallman (2012) found that coordination characteristics in an alliance and some contextual factors influence alliance formation and the level of equity investment. Evidently, given the nature of these governance modes, it can be a muddy task to definitively distinguish strategic alliance deals from acquisitions. In the interest of this study, an equity cut-off is used for only for non-JVs to differentiate between alliances and acquisitions. We followed the distinction adopted by Zaheer, Hernandez, and Banarjee (2010). They considered a deal to be an acquisition if an acquiring firm obtained a majority of the target's equity (50.1\%); any other types of equity or non-equity deals, including JVs, are included as alliance deals.

\section{Relevant Theoretical Frameworks}

\section{Relational Mechanisms}

One dimension of alliance relationships that has received considerable empirical attention in the last few decades is the extent to which firms are similar or related to their alliance partners (Saxton, 1997, Hull, Slovinsky, Wharton, and Azimi, 1988; Westney, 1988) and how this influences alliance outcomes. In this research stream, scholars have indicated the importance of firm-specific, partner-specific, and relational attributes that make an inter-firm alliance successful. Within this theoretical tradition, the relational view of inter-firm relationship (Dyer and Singh, 1998; Dyer and Hatch, 2006) suggests that value creation in an inter-organizational context is contingent upon the existence of effective relational mechanisms, such as relation-specific investments, knowledge sharing, complementary partner resources, and routine-building. Furthermore, Lane and Lubatkin (1998) coined the term relative absorptive capacity, defined as the ability of a 
focal firm to recognize and assimilate valuable information and knowledge from a partner. Relative absorptive capacity has been found to be an important prerequisite for value creation in an inter-firm exchange.

\section{Organizational Learning}

Scholars of organizational learning have long theorized that corporate strategies are influenced by activities that stem from: a) organizational routines based on the interpretation of the past (Cyert and March, 1963; Nelson and Winter, 1982), b) historydependent actions that provide feedback about outcomes (Lindblom, 1959; Steinbruner, 1974; Greve, 2003) and c) relations between organizational outcomes and future actions based on those outcomes (Simon, 1955; Siegel 1957; Olsen, 1976).

The widely prevalent term "routine" includes the rules, procedures, conventions, practices, strategies, and technologies that are adopted by organizations and through which they conduct their day-to-day operations. It may also include norms, belief structures, frameworks, paradigms, codes, cultures, and knowledge that strengthen, elaborate, and contradict the formal routines. Routines may originate at the level of an individual cognition or behavior, but based on their frequency of use, they may gradually become independent of the individual actors who execute them, and expand up to the boundary of an organizational and inter-organizational context. However, it is important to recognize that under certain circumstances, organizational experience and routines are not conserved in their entirety. Knowledge, learning, and routines may disappear from an organization's active memory and future reinforcement because of limits on organizational control, lack of legitimacy of a practice, personnel turnover, different types of distance within the organizational boundary, rate of learning, etc. 
Over the last several decades, a considerable body of research has suggested that organizational learning based on prior experience drives important future strategic actions (March and Simon, 1958; Cyert and March, 1963, Nelson and Winter, 1982). At the core of this argument is the assumption that firms may be able to improve their future behavior relying on the experience, outcomes, and feedback received from past actions (Cyert and March, 1963; Miller and Friesen, 1980). The nature and scope of their experiences enables firms to improve routine-based learning and enhances the likelihood of the routine/learning being used in future relevant activities. Given that organizational learning and feedback are a crucial part of firms' future strategic behaviors, we consider the strategic performance implications for similar corporate actions.

The view that learning stems from feedback, grounded in the Carnegie school of thought (e.g., Cyert \& March, 1963), emphasizes the role of organizational outcomes from prior actions and suggests that these outcomes determine a firm's future behavior (Greve, 2003). Some theoretical work in the learning tradition has implied that routines and feedback work together to shape and reinforce firms' future behavior (Levitt and March, 1988). Haleblian, Kim, and Rajagopalan (2006) have examined the combined effect of routines and feedback based on prior acquisition experience, in the context of the US commercial banking industry. Building on these notions of routines and feedback from previous organizational actions, this study seeks to demonstrate that an alliance partner's likelihood of a future acquisition of its partner is positively related to the nature of alliance experience with the target firm immediately prior to the acquisition. 


\section{HYPOTHESES DEVELOPMENT}

Considering the nature and focus of our research questions, we formulate the following five hypotheses. The relationships proposed in these hypotheses are illustrated in the following conceptual model (Figure 2):

\section{Role of Deal Characteristics in Building Relational Mechanisms}

According to the seminal piece of Levitt and March (1988), even within a consistent and accepted set of routines for actions and practices, only part of an organization's memory is likely to be evoked for its future application. In this case, the recency of a certain organizational experience is very critical. Therefore, we build on this premise that in the context of a post-alliance acquisition attempt, the most valuable aspects of experience an acquiring firm can gain are from its partnering experience with the target firm. Assuming that there is a connection between the alliance deal and postalliance strategic actions of a firm with its alliance partner, we propose that positive or negative dynamics of inter-organizational experience and reciprocity would further signify the future outcome of a partnership. We believe that the following steps summarize this relational mechanism. First, alliance deals provide a focal firm with the opportunity to receive partner-specific learning, feedback, and to build partner-specific routines. Second, when a focal firm's post alliance experience/exchanges with its partner are satisfactory, it validates the focal firm's assumptions that they have developed a certain level of competencies required to successfully work together (Haleblian, Kim, and Rajagopalan, 2006). Finally, it elevates the confidence of a focal firm's decision-makers 
to undertake a post-alliance acquisition attempt based on both the performance feedback and partner specific experience from the alliance deal.

Alliances and acquisitions being complex events, the causal relationship between performance and the factors contributing to the performance may not very be clear (Sirower, 1997). Therefore, learning from the performance feedback from an alliance requires a focal firm to carry out a meaningful evaluation of the performance (Haleblian, Kim, and Rajagopalan, 2006), beyond merely the financial measure of performance. Such an evaluation may appear to be a difficult task when varying performance levels of multiple activities may demand time and cognitive effort from the decision makers. Therefore, we argue that different transaction- and relation-specific factors become important to decision-makers as they consider post-alliance strategic choices. Behavioral theorists have suggested that under such ambiguous conditions, decision makers tend to rely on the most recent information to reduce their cognitive burdens and simplify information processing (Hogarth \& Einhorn, 1992; Steiner \& Rain, 1989). Following these lines of reasoning, we believe that partner-specific and dyadic conditions of the most recent alliance deal are likely to result in a positive or negative evaluation of an interfirm relationship. In other words, reciprocity, mutuality, and emerging dynamics of an inter-organizational relationship would play the role of a precursor to the success of a higher level of post-partnership resource commitment. Accordingly, in the following sections we identify a number of deal specific and relational characteristics supported by the extant literature that are central to studying this collective phenomenon of alliances leading to acquisitions. 


\section{Prior Partnership between Firms}

Some scholars suggested that at the individual firm level, a firm's experience with various prior partners contributes to its relational capabilities (Dyer and Singh, 1998; Gulati, 1999, 2007; Kale et al., 2002; Lorenzoni and Lipparini, 1999). Such experience contributes to the development of alliance management routines that assist firms in partner selection, the choice of appropriate governance mechanisms, and the effective management of inter-organizational relationships. These relational capabilities, in turn, are likely to enhance value creation in subsequent alliances (Anand and Khanna, 2000).

Firm dyads with repeated transactions develop relational absorptive capacity (Wang and Zajac, 2007). Experience in each inter-organizational deal is important to the creation of routines and capabilities, because each successive deal carries intrinsic value, creates experience, generates feedback, and provides information about a potential target firm's capabilities (Arikan and McGahan, 2010). These inter-organizational mechanisms typically precede partners' investments in relation specific assets and knowledge-sharing routines as well as reliance on complementary resources and trust-based governance (Dyer and Singh, 1998). The emergence of such relational mechanisms depends on the interactions with partners (Gulati and Sytch, 2007, 2008; Zaheer, McEvily, and Perrone, 1998), and thus is tied to the history of prior relationships with specific partners.

Consequently, benefits that can derive from partnering experience are less fungible across alliances with other partners (Gulati, Lavie, and Singh, 2009). For instance, inter-firm trust with a given partner does not imply trust of another partner; knowledge sharing routines that economize on transaction costs with a certain partner may not be applicable in relationships with other partners; and mutually agreed upon conflict resolution 
mechanisms that are applied in recurrent alliances with the same partner are not necessarily applicable in all other alliances (Gulati, Lavie, and Singh, 2009). Therefore, multiple types of experience benefits are available only in recurrent alliances with the same partners.

Prior studies suggested that at the dyadic level, the partnering experience of two firms may reduce opportunistic behavior in subsequent alliances between them by guiding partner selection decisions and by fostering mutual trust, reciprocity, informal obligation, and loyalty (Gulati, 1995; Gulati and Wang, 2003; Kogut, 1989; Park and Kim, 1997). Consequently, partners are more willing to commit critical resources (Dyer and Singh, 1998; Zajac and Olsen, 1993) and cut back on the control and monitoring costs in such recurrent alliances (Gulati and Singh, 1998; Williamson, 1985). Experience accumulated in recurrent alliances with the same partners also contributes to the capacity of partners to resolve inter-firm conflicts (Kale et al., 2000; Simonin, 1997), reduces transactional uncertainties, and enhances the predictability of alliance success. The above discussion altogether enables us to deduce that alliance deals are generally more satisfactory to partnering firms when agreements involve recurrent partnerships, which may invoke the intent in the partners to pool resources for greater integration through a majority-share acquisition. Given the previous lines of reasoning, we expect that prior alliance experience with a partner will have a positive effect on the likelihood of a future acquisition attempt. Thus, we predict the following:

Hypothesis 1 (H1): Prior partnership agreement between a dyad of alliance partners would increase the likelihood of a post-alliance acquisition attempt between the same partners. 


\section{Multi-nationality}

In inter-organizational relationships between firms from different countries, the dyad of the firms typically face higher levels of geographic, economic, cultural, psychic, administrative and political distance (also collectively referred to as institutional distance) vis-à-vis a uni-national setting (Verbeke, 2010). A very widely accepted body of research building on the contributions of North (1990), Scott (1995), Kostova (1999), and Peng (2008) theorize on the complexities created by institutional differences that underlie cross-border strategic alliance (Phene and Tallman, 2012; Tallman and Phene, 2007; Gulati and Singh, 1998) or merger \& acquisition settings (Dikova, Sahib, and Witteloostuijn, 2010; Meyer and Altenborg, 2008; Wang and Zajac, 2007, Morosini, Shane, Singh, 1998). In view of the literature, we argue that creation of relational mechanism in a dyadic context takes substantial effort on the part of partnering firms and imposes further costs on their exchange process. An alliance with a partner from the same national context (even after recognizing sub-national differences) provides firms with a more stable and consistent learning context. In such a context, experience is accumulated more efficiently, resulting in lower learning costs, and exhibiting faster learning compared to an unfamiliar environment where communication and collaboration takes greater effort (Gulati, Lavie, and Singh, 2009).

It is also believed that home country differences in a relationship dyad may become more complex than micro-level differences (e.g., differences in organizational culture) (Weber, Shenkar, and Raveh, 1996). These differences may entail issues ranging from problems with "evaluating information on research output and productivity, calculating hypothetical synergies and formulating optimistic business plans based on 
increased innovation capacity, towards actually trying to make the acquisition [an interfirm collaboration] work by bundling assets and capabilities in practice" (Verbeke, 2010: 41). These distance components that are embedded in national differences between the host countries of firms, therefore, may deteriorate inter-firm exchanges and complicate the process of building common routines and relational capabilities in an alliance. Furthermore, higher institutional distance underlying national difference makes it more difficult for partnering firms to achieve optimal commonality in their dominant logics (A dominant logic reflects "[firms'] entrenched habitual modes of functioning based on prior successes and failures and the strategic contingencies they have had to face in the past" (Cote, Langley, and Pasquero, 1999). However, efficient and effective integration of an acquired company with its acquirer usually requires the latter to institutionalize at least some of its routines in a post-acquisition integration (Verbeke, 2010; Verbeke and Kenworthy, 2008).

Given such an institutionally challenging scenario of inter-firm exchange, managers of a focal firm are likely to have a negative evaluation of a successful postacquisition success with a partner in such a strategic alliance, and to not consider a postalliance acquisition. As a result, we anticipate that national and regional differences between partner firms may reduce a focal firm's motivation to go for a deeper level of integration with its partner:

Hypothesis 2 (H2): Differences in national origin (i.e., a cross-border deal) of alliance partner firm dyads will decrease the likelihood of their post-alliance acquisition attempt. 


\section{Ownership Type Difference}

Increasingly global, dynamic, and competitive environments have encouraged firms to rely on external sources for supplementary and complementary resources and capabilities (Santoro and Chakrabarti, 2002). As a result, interfirm relationships are being formed between and among various types of large multidivisional, subsidiaries, public, private, and not-for-profit organizations. But, these different types of organizational ownership forms are distinct from one another due to their diverse pools of resources, knowledge, capabilities, ownership, management, and governance structures (Harrison et al., 2001).

Evidently therefore, partnering with organizations of different governance structures and purposes would pose a greater challenge for partnering firms in terms of resources and knowledge sharing, effective and efficient communication, development of organizational routines, and so on. For instance, publicly owned companies, more so than privately owned ones, are expected to comply with a variety of national and international regulations. At a broader level, dissimilar organizations in terms of ownership variety are likely to have different goals, decision-making processes, and organizational systems that may cause communication and coordination difficulties in inter-organizational settings, resulting in increased transaction costs. It may even cause reduction in overall value creation potential from an alliance deal and create issues with post-alliance integration (Jiang, Tao, and Santoro, 2010). Wang and Zajac (2007) found that considering the potential for synergy creation, more similar firms may prefer acquisitions over alliances due to greater value-creation opportunities. They further argued that similar firms that have greater duplication in routines and resources may be able to eliminate many 
redundancies by pooling their resources together. As a result, the combined firm, i.e., an acquisition, is likely to be more efficient (Wernerfelt, 1984; Dussauge, Garrette, and Mitchell, 2000). Moreover, when two firms are similar, organizational operations and transactions are more efficient within the boundary of a firm vis-à-vis in an interorganizational relationship, which is suggestive of greater realization of synergies (Garrette and Dussauge, 2000).

As a result, we argue that an alliance deal involving parties of different ownership structures reduces the potential for a higher partnership satisfaction between the partners, and may complicate the routine and capability development process, ceteris paribus. The difficulties in mutuality and reciprocity during the duration of an alliance are likely to have a negative effect on the confidence of decision makers as to whether a greater level of integration and commitment could be more beneficial in the form of an acquisition especially given a more legally binding context of an acquisition deal. Therefore, we predict the following effect stemming from the difference in partnering firms' ownership types:

Hypothesis 3 (H3): Difference in the organizational ownership types (e.g., public, private, or subsidiary) between partner firms involved in a strategic alliance would decrease the likelihood of their post-alliance acquisition attempt. 


\section{Intangibility}

Sharing and/or pooling resources (namely, financial assets, brand reputation, knowledge, capabilities) and exchange of them are very fundamental to strategic alliance deals. Several studies (e.g., Eisenhardt and Schoonhoven, 1996; Gulati, 1999; Rothaermel, 2001; Van De Ven and Walker, 1984) used resource dependence theory (Pfeffer and Salancik, 1978) and the resource-based view of the firm (Penrose, 1959; Wernerfelt, 1984; Barney, 1986 and 1991) to investigate the important of resources in the context of strategic alliances. From a resource-based perspective, equity investments, including majority share acquisitions, offer preferential access to complementary resources of partnering firms that are sought in alliances (Colombo, Grilli, and Piva, 2006). From the perspective of the knowledge-based view, alliances provide partners with an opportunity to access and combine knowledge (Grant and Baden-Fuller, 2004). For that matter, many alliances are formed for purposes of new product development (Rothaermel and Deeds, 2004), knowledge production (Kale and Singh, 2007) or creation of new capabilities (Colombo, 2003), which require the transfer and recombination of existing knowledge (Khanna, Gulati, and Nohria, 1998). According to Grant and BadenFuller (2004), these "knowledge accessing” inter-firm alliances involve cooperative relationships that are not fully defined either by formal contracts or by ownership. In terms of Williamsonian transaction cost economics, these inter-organizational forms fall between the polar extremes of markets and hierarchies, making these cooperative relationships “intermediate” organizational forms (Borys and Jemison, 1989; Powell, 1987; Thorelli, 1986) that are open to evolution. According to complementary perspectives (Rugman and Verbeke, 2003) that integrate the resource-based and the 
knowledge-based views of the firm, the role of coordination in governance mode decisions play a critical role in the projection of other organizational forms.

Tangible characteristics (e.g., financial indicators, tangible resources, such as cash or cash equivalents) of an alliance deal enable partnering firms to realize whether they would be able to create new value from an alliance if they were to attempt an acquisition. In this particular hypothesis, we argue that that alliance outcomes would vary depending on the intangible forms of resources (e.g., knowledge) underlying an inter-firm exchange. When an alliance involves a knowledge-based firm, research and development (R\&D) agreement, or a technology-based participant, the intangibility elements of the interorganizational relationship may hinder a focal firm's accurate evaluation of a partnering firm's value. This is likely to blur a partner's post-alliance intent to attempt a subsequent acquisition. This reasoning stems from the following sources: a) Technology-based alliances frequently result in competitive learning, i.e., gaining greater power relative to the partner. This increases the likelihood of a partner to walk away from a deal, reducing the likelihood of alliance survival or a greater level of commitment through a subsequent M\&A (Parkhe, 1993; Yan, 1998); b) Due to the intangibility attribute of resources possessed by knowledge-based firms, the value of their resources and capabilities (with the exception of radical innovation or certain patents) are not easily quantified or assessed by a partnering or acquiring firm (Arend, 2004). This hinders a firm's ability to foresee the level of synergy that could potentially be achieved through further resource/knowledge pooling through a majority-equity acquisition. Therefore, we argue that knowledge, R\&D partnership, and technological characteristics of an alliance deal 
impair the abilities of focal firms to effectively evaluate the true future potential for their alliance partners.

Furthermore, Lane and Lubatkin (1998) opined that relative absorptive capacity in a partnership depends on specific attributes of alliances, such as, the relatedness of partners' knowledge. Absorptive capacity of firms, which is defined by Cohen and Levinthal (1990) as a firm's "ability to recognize the value of new information, assimilate it, and apply it to commercial ends", is an important prerequisite for value creation in inter-organizational relationships. Some studies suggest that performance benefits tend to accumulate more readily to firms that have low to medium knowledge difference and firm that are capable of accessing knowledge between organizations (Inkpen and Tsang, 2005; Grant and Baden-Fuller, 2004).

Szulanski (1996) pointed out that knowledge is sticky for a variety of individual and organizational conditions and despite organizational efforts, it does not move easily in an inter-divisional or inter-firm context. One of the key findings in the area of knowledge management is that integration of knowledge within or between firms is a very complex phenomenon (Grant, 1996; Almeida and Phene, 2004; Phene and Almeida 2008). The above discussions suggest that the elements of intangibility in an alliance deal may negatively affect the inter-firm relationship, and thus reduce further future resource commitments between one another.

Hypothesis 4 (H4): When an alliance agreement involves transfer of intangible resources and/or capabilities, or partnership between knowledge or technology based firms, the likelihood of a post-alliance acquisition attempt would be reduced. 


\section{METHODOLOGY}

In addition to the detailed description of the sample, data sources, variables, and measures used to empirically test the hypotheses for the study, the following section provides a quick snapshot of these important aspects of our research methods:

\section{Sample and Data Sources}

Data on alliance and mergers \& acquisitions (M\&A) announcements are extracted for the years 1990-2012. The initial sample, consisting of all the entries of alliances and M\&As, is compiled from Security Data Corporation (SDC) Platinum database's M\&A and joint-venture modules. We started by extracting data on all the alliance deal announcements during 1991-2010 and M\&A announcements during 1991-2012. Given our outcome variable, we took into consideration all the acquisitions there were publicly announced (i.e., an acquirer made an actual attempt at purchasing a target) within that time period, regardless of whether they were completed or abandoned at a later time. Although some acquisition attempts do not realize after months and years of negotiation, the public announcement of an acquisition attempt is considered an important indicator of an acquirer's interest in a target firm (Dikova, Sahib, and Witteloostuijn, 2010). Next, we excluded the partnerships that involved government agencies and/or not-for-profit organizations, since post-alliance acquisitions in these alliances may not be a viable option on regulatory grounds. Then, for each deal we determined whether the acquirer and target had partnered to form an alliance at any point before the acquisition announcement. Finally, we augmented our dataset, by extracting financial variables from the Compustat database. 


\section{Measures}

\section{Dependent Variable}

Acquisition Attempt: Since we are interested in partnering firms' post-alliance acquisition behavior, the dependent variable of the study is a dichotomous categorical variable denoting a specific type of post-alliance strategic action, which is whether a firm attempted a majority share (50.1\%) acquisition or not after forming an alliance with the same partner. All the other non-equity or equity based JVs are coded as alliance. This variable, therefore takes the value of 1 if a firm, previously engaged in an alliance agreement made a public announcement of an acquisition attempt (i.e., regardless of whether it was completed or abandoned) to acquire a partnering firm, and 0 otherwise. We followed the operationalization followed by Zaheer, Hernandez, and Banerjee (2010) to determine an acquisition.

\section{Explanatory Variables}

Prior partnership (H1): This is a dichotomous variable taking the value of 1 if the alliance deal involves two firms that had prior partnering agreements with one another (i.e., besides the only one that resulted in an acquisition attempt) in any previous year in the entire dataset, and 0 otherwise. We created this variable following several studies that measured this construct (Gulati, Lavie, and Singh, 2009; Zollo, Reuer, and Singh, 2002; Gulati, 1995). To operationalize this variable, we created a new variable for recurrent partnerships by searching the entire dataset for previous alliances between the same firms.

Multi-nationality (H2): this is also a dichotomous variable. It is counted as 1 if the alliance deal involves two firms from the different countries and 0 if the firms are 
from the same country as coded by alliance nation code in SDC Platinum database. We followed Zaheer, Hernandez, and Banerjee (2010) to operationalize this variable.

Ownership Type Difference (H3): This dichotomous variable captures the difference in the ownership/governance structure of the partnering firms in question. However, partnerships involving not-for-profit firms and government agencies are excluded from our sample given that even when the communication or coordination is favorable with a government agency or non-profit seeking organizations, acquisition is not an option. This variable therefore is counted as 0 when alliance partners involve firms with the same organizational type (public-public, private-private, etc.), and 1 if the deal engages more than one organizational ownership type (public-private, private-subsidiary, and so on). This variable is consistent with the measure used by Jiang, Tao, and Santoro (2010).

Intangibility (H4): This variable measures the elements of intangibility or tacitness involved in an alliance deal. This is also a dichotomous variable that takes the value of 1 if the alliance deal involves transfer of technology, an R\&D partnership, or if at least one of the allying firms operate in a technology-based industry, and otherwise 0 .

\section{Control Variables}

We used several control variables that are found by previous studies to be correlated with acquisition attempts. Following is a description of these variables:

Acquisition Experience (CV1): We controlled for the effect of prior organizational learning of the acquiring firms. It is measured in terms of acquisition experience by counting the number of prior M\&A deals completed by the focal firm within 4 years prior to the focal deal (Haleblian, Kim and Rajagopalan, 2006). To capture this variable, we 
code a deal as a focal one when a prior alliance between two companies results in an acquisition attempt (which is our dependent variable). In this case the focal firm is the one that makes an acquisition attempt (or the acquirer).

Alliance Experience (CV2): Consistent with Gulati et al. (2009), we count the number of prior alliance deals formed by the focal firm within 4 years prior to the focal deal and follow the same calculation method that we did for acquisition experience to operationalize alliance experience to create this variable. The only exception is that we apply the formula to count the number of alliance deals undertaken by a focal firm, instead of number of acquisitions. This way we use a proxy for an acquirer's organizational learning in alliance activities by capturing the number of prior alliance deals.

Number of Alliance Partners in a Deal (CV3): Prior research suggests that the number of alliance partners, especially when more than two partners are involved in an alliance, are likely to complicate the interactions of the parties in a deal. Therefore, we control for this effect. We coded this variable 1 for alliances involving two participants, and for any other number of alliance partners in a deal, we coded 0 .

Acquirer's Public Status (CV4): This variable captures whether the partnering firms are publicly owned/traded. Publicly owned companies, more so than privately owned ones, must comply with national and international regulations throughout all phases of trading activities (Dikova, et al., 2010). This feature of publicly owned companies may cause delays in the completion of an acquisition deal or a focal firm's motivation to acquire a publicly held target (Weston, Mitchell, and Mulherin, 2004). "Public" status of the participants was coded 1, 0 otherwise. 
Target Attractiveness (CV5): A highly attractive target is likely to receive more attention from potential acquirers if they are financially better performing firm. To proxy for a firm's attractiveness as a target for acquisition, we gauge its financial strength in terms of Return on Equity (ROE). The higher the value for this measure, the higher a firm's attractiveness as a target.

Finally, we used binary variables to control for year-specific variations.

\section{Statistical Technique}

Hypotheses of this study predicted the likelihood of post-alliance acquisition given a number of explanatory variables. The dependent variable of the hypotheses is a binary variable. Given the dichotomous nature of these dependent variables, use of a logistics regression (logit) is appropriate (Pindyck and Rubinfeld, 1981; Greene, 1997; Hosmer and Lemeshow, 2000). A logit model captures that the probabilities will be within the $(0,1)$ range. The statistical analyses for logit models are based on binomial distribution and have several advantages, including: a) there is no need for explanatory variables and dependent variable to be normally distributed, b) the model can handle nonlinear effects, and c) it allows for explanatory variables to be categorical (Menard, 2001).

We estimated the logit model using a maximum likelihood estimation procedure that presents outputs in parameter estimates that are consistent and asymptotically efficient for large samples. To test the significance of the entire logit model, we used the model log likelihood chi-square, which is analogous to the multivariate F-test in linear regression testing the null hypothesis where all coefficients are zero. The parameters (logits) estimated are the natural log of the odds ratio and are interpreted in the following 
manner: a positive (negative) logit means that the odds that the binary dependent variable equals 1 increase (decrease) when the independent variable increases (decreases). In other words, a positive coefficient designates a positive association and a negative coefficient designates a negative association. In addition, because we have panel data (i.e., multiple dimensions, years, and observations per firm that may not be independent), we use STATA's 'xtlogit' command with fixed effects that group observations based on firm identification.

\section{RESULTS AND DISCUSSION}

Table 1 and 2 provide the bivariate correlation matrix and descriptive statistics (i.e., mean and standard deviations) for our measures. A glance at the correlation matrix reveals that there are no significantly high correlations that could confound results due to multicollinearity that lead to variance inflation. The results showed that among the predictor variables, including the control variables, the variance inflation factor (VIF) did not exceed the suggested cutoff limit of 10 (Kutner, Nachtsheim, and Netter, 2004; Kleinbaum, Kupper, and Muller, 1988). More specifically, all of these VIF estimates were below 8 . Therefore, the assumption for the existence of no significant threat of multicollinearity was met.

Table 3 presents the logistic regression results we used to test hypotheses 1-5. The hypotheses examine the proposed relationships between post-alliance acquisition attempt and various deal and partnership related variables. This table first introduces the control variables to create a baseline model against which to compare our subsequent hypothesis 
tests. The direct effect variables, namely prior partnership, multi-nationality, organizational ownership type difference, and intangibility elements of the deal are introduced in the subsequent models along with the control variables.

Model I in Table 3 is the baseline model introducing only the control variables. Model 1 tests the first hypothesis regarding prior partnership. The first hypothesis expected a positive relationship between prior partnership between alliance partners and the likelihood of a subsequent acquisition. Model II tests H1 and finds strong support for the hypothesized relationship in $\mathrm{H} 1(\mathrm{p}<0.01)$ in the opposite direction than what we anticipated.

Based on the logic of institutional difference embedded in international business, we anticipated negative implications of national difference in partners' relational exchange in an alliance setting and its possible bearing on partners' post-alliance strategic action. The results of this relationship are represented by Model III. The model suggests strong significant support for H2 $(\mathrm{p}<0.01)$, fully consistent with our arguments that national difference between the partners engaged in an alliance deal is likely to reduce the possibility of a post-alliance acquisition attempt.

Our third hypothesis predicted a negative relationship between the difference in organizational ownership type and a post-alliance acquisition attempt. Prior literature suggested that difference of organizational structure and purposes may impose greater complexities in the process of relational exchanges in an alliance deal. This hypothesis $\mathrm{H} 3$, tested by Model IV, was also found to be strongly significant $(\mathrm{p}<0.01)$ in the predicted direction as to a negative association. The data suggests difference of 
organizational ownership type undermines a focal firm's desire to acquire its current alliance partner.

Consistent with our prediction, $\mathrm{H} 4$ was strongly supported $(\mathrm{p}<0.01)$, suggesting a negative association between the existence of intangibility elements in an alliance deal and post-alliance acquisition attempt. This hypothesis was based on the challenges of relational exchanges in inter-organizational contexts that are rooted in knowledge-based theory of the firm. Model V in table 3 tests this relationship. With a significant and negative coefficient $(\mathrm{p}<0.01)$, our analysis suggests that $\mathrm{H} 4$ was also strongly supported.

The overall results of our analyses generally confirm our overarching theoretical arguments. Specifically, the results offer support for our hypotheses regarding the likelihood of relational and deal specific characteristics, namely, national difference (H2), ownership type difference (H3), and intangibility elements (H4). These empirical findings indicate that certain relational mechanisms are shaped by the dyadic and/or deal characteristics of the alliance deals, and may influence firms to make a post-alliance acquisition attempt when the setting of a prior alliance is favorable for the partners to have mutually satisfactory partnering experience.

Support for $\mathrm{H} 2, \mathrm{H} 3$, and $\mathrm{H} 4$ indicate the importance of dyadic and deal-specific characteristics that have strategic implications for future target selection. Three such sets of assumptions contribute to these relational dynamics:

a) Increased barriers to inter-firm communication, co-ordination, conflict resolution, increased learning and routine-development costs between alliance partners influence the relational mechanism as evidenced by a potential acquirer's perception of a future target's attractiveness. 
b) Multi-national setting, organizational type difference, and intangibility involved in an alliance deal lead to difficulties in developing a stable and consistent relational experience in the inter-organizational exchange process, which as a result make a potential target less attractive.

c) Prior partnering experience contributes to relational capability development to encourage a future governance change (Dyer and Singh, 1998; Gulati, 1999, 2007; Kale et al., 2002; Lorenzoni and Lipparini, 1999) especially in terms of further control and resource commitment through acquisition.

H1 tested by Model II that sought for a relationship between recurrent partnership between an acquirer and a target firm and the likelihood of post-alliance acquisition was not supported. However, we found it to be strongly significant in the opposite direction, i.e., a negative coefficient, in respect to what we anticipated. This suggests that when partners are involved in more than one alliance deals with each other, the likelihood of an acquisition attempt will decrease. In other words, partners are less likely to engage in a post-alliance acquisition when they have had multiple partnership deals with the same partner in the past. This is quite contrary to the prior findings in strategic alliance research (Gulati and Sytch, 2007, 2008; Wang and Zajac, 2007; Zaheer, McEvily, and Perrone, 1998). One possible explanation may be that where partners are already enjoying specific transaction, strategic, and financial benefits emanating from partnerspecific experience (Gulati, Lavie, and Singh, 2009), they are less likely to take a alternate action that may threaten the trust and mutuality underlying the status quo. Given the multiplicity of alliance agreements between the partners, the partner-specific dependency rises. Thus, partners may become less motivated to change the governance 
structure from a relatively hands-off relationship to a dominant or controlling role by making an acquisition.

\section{LIMITATIONS AND IMPLICATIONS}

Overall, this study attempts to contribute to corporate development activities literature by synthesizing findings of both alliance and M\&A research streams. While this study represents an important step towards understanding the factors relating to a focal firm's post-alliance M\&A strategy, a few aspects of our research model could complicate our conclusions, if they are not considered with caution. First, since we focus on announced deals based on publicly available data, we are unable to evaluate how the managerial decision-making process may influence a post-alliance acquisition attempt. In other words we make an assumption that the short and long period of inter-organizational relationships and/or actions influence a firm's future strategic actions. Hence we make the assumption that the dyadic nature of partnership-specific characteristics and exchanges in an alliance deal that are beyond a focal firm's immediate control play an important role in predicting a focal firm's post-alliance acquisition attempt. Future casebased and survey-based research may seek to examine whether these managerial factors play a role in post-alliance acquisition decisions. Second, our empirical results may be somewhat limited by methods or practices used in the data collection of the data sources. Despite our sincere attempts to maximize the data points for this study, given the reporting standards and availability of data in SDC Platinum database we had to exclude several of the alliance and acquisition deals. However, it was no exception to many other rigorous studies that used the same data source, including the ones published in leading strategy journals. 
Given the emerging body of research in this cross-form inter-organizational context, future survey-based or qualitative studies may be conducted to examine the accumulated alliance experience of both acquiring and target firms for post-alliance acquisition strategies. Such research may also confirm whether the observed effects of relational mechanisms hold true for other modes of alliances, in populations of smaller firms, or firms from developing and/or emerging economies. However, it is also important to realize the challenge of data-collection on alliances that involve less formal arrangements and in cross-cultural contexts, especially when the archival data sources are inadequate.

\section{CONTRIBUTION}

Previous studies have made substantial progress in understanding various sets of firm, industry, contextual, and relational characteristics that determine the choice between/among alternative governance structures, i.e., different forms alliances, mergers $\&$ acquisitions, partner selection in alliances and acquisitions. However, this study focused on understanding a cross-form choice between alliances and acquisitions, which required synthesis of two parallel streams of research. The objective was to understand whether dyadic exchange in an alliance may positively or negatively associate with the likelihood of post alliance acquisition. Despite some limitations, we believe, this study informs strategy researchers and practitioners with important insights about inter-firm relationship mechanisms. The broader implication of the study, evidently, is taking an integrative approach to understanding interdependency of experience and learning across 
various types of corporate development activities (i.e., multi-task setting). Specific contributes of this study include:

- Identifying several important deal/dyadic characteristics, e.g., multi-national context, organizational type difference, and intangibility which are found to undermine the relational dynamics of an inter-organizational experience and have implications for future strategic outcomes.

- Explaining the process how the relational mechanisms of an alliance lead to very important decision making at the corporate level phenomenon of future target selection for acquiring firms.

- Extending strategy literature by highlighting the relevance of path-dependent and cross-form nature of organizational learning for inter-organizational strategies. 
STUDY II:

\section{DOES PRIOR ALLIANCE EXPERIENCE OF AN ACQUIRER SPILL OVER TO ITS ACQUISITION PERFORMANCE?}

\section{INTRODUCTION}

In their work on the myopia of learning, March and Levinthal (1993) described the hazards of increasing specialization in a particular domain of learning. The assumption is that the knowledge and experience gained in one organizational activity can hinder learning in another activity, implying a potential for negative experience spillover effects. In contrast, Cohen and Levinthal's (1990) theory of absorptive capacity recognizes a multitask perspective of learning. They suggested that firms, having developed substantial knowledge in a certain domain, may become more skilled at expanding the span of their competence into excelling in related contexts, which acknowledges positive learning effects across organizational activities. In view of the vast literature in organizational learning and given the recent scholarly contributions, it is evident that the performance outcomes of organizational learning across various corporate development activities remains as an area open for further research. The framework for learning spillover, therefore, is of inherent interest to strategy scholars and practitioners alike, not only because of their managerial relevance, but also because there appears to be intriguing inconsistencies to explain the processes that are not evident in more traditional, single-task learning models (Zollo and Reuer, 2010).

A number of recent studies implied that there might be experience spillover effects or interdependency of learning between strategic alliance and acquisition activities at the dyadic (i.e., partner-specific) level (Zollo and Reuer, 2010; Zaheer, Hernandez, and Banerjee, 
2010; Agarwal, Anand, Bercovitz, and Croson, 2012). Each of these handful of papers considered research questions that explain this experience spillover effect from a dyadic level of partner-specific learning. However, in this study we are guided by the following broad questions: Does alliance experience, e.g., organizational memory, routines, and their recency at the program level (i.e., beyond just partner-specific learning) of a focal firm's alliancespecific learning have any transfer effects across its corporate development activities through acquisitions? This central question leads us to ponder additional questions: Which aspects of alliance-based learning can potentially explain the focal acquirer's acquisition performance? Even more specifically, we are interested in examining whether frequency, recency, and relatedness of different dimensions of prior alliances of an acquirer, beyond the dyad-level experience, relate to superior acquisition performance. To explain this phenomenon, we rely on the concepts of procedural, declarative, and transactive memory previously used by organizational learning scholars.

\section{THEORETICAL BACKDROP: TRANSFER OF LEARNING IN A MULTI-TASK SETTING}

In this section, we trace the building blocks of organizational learning in a multi-task setting highlighting the contributions of cognitive psychologists and researchers of organizational learning:

\section{Experience as a Source of Organizational Memory}

Not all organizational experience and learning are equally or universally useful. Cognitive psychologists have long established that the context, elements, and organization of knowledge are critical to the directionality (vertical or lateral) of the 
transfer of learning (Thorndike, 1901, 1903; Gagne, 1966; Tversky, 1977). Furthermore, organizational learning scholars have long opined that since experience becomes less useful over time, the benefits of prior experience may not increase monotonically with the amount of experience that a firm accumulates (Argote, 1999; Barnett, Greve, and Park, 1994; Hayward, 2002). This suggests that the timing of learning is critical. For instance, environmental changes (e.g., change in regulations, industry standards) may lead routines, procedures, and contexts to become less relevant to obsolete. For example, Haleblian, Kim, and Rajagopalan (2006) suggested that certain regulatory changes in the banking industry forced banks to review their existing acquisition strategies, to modify their templates for making acquisitions, and to search for new practices. Because those regulatory changes marked significant shifts in the industry, a bank's acquisition experience before the changes might not represent viable repositories for future learning. Such experience might even lead firms to adopt outdated routines and undermine their performance by replicating strategies that worked well under different circumstances (Barney and Hesterley, 1996).

\section{Organizational Routines as Elements of Learning}

Organizational routines are believed to be the repository of organizational capabilities (March and Simon, 1958; Cyert and March, 1963; Nelson and Winter, 1982). Research on routines as repositories of organizational capabilities (Dosi, Nelson, and Winter, 2000; Winter 2000, 2003; Zollo and Winter, 2002) has emphasized that organizational routines do not just preserve the past, but, being a repository of organizational capabilities, they also shape how deliberate learning occurs inside firms, thereby paving the way for the future development of the firm (Winter, 2000; Zollo and 
Winter, 2002). It is believed that strategic decisions are influenced by routines, i.e., repetitive patterns of activity and capabilities, that develop from organizational experience (Nelson and Winter, 1982). A considerable body of research established that routines are those elements of organizational memory that drive important organizational actions and serve as the repository of organizational capabilities (March and Simon, 1958; Cyert and March, 1963, Nelson and Winter, 1982). Additionally, greater experience with a particular type of repetitive behavior provides a platform for firms to build and refine routines, and enhances the likelihood of the routine being used further yielding superior organizational outcomes. Given that routines are a crucial part of how firms accomplish their tasks, in this section, we state the relevance of organizational experience as it relates to the transfer of learning from a focal firm's alliance activities to acquisition performance.

\section{Context of Experience and Learning}

The literature on learning in the context of alliances covered several types of experience: general collaborative experience, industry-specific alliance experience (e.g., technology-based deals), and partner-specific alliance experience (Gulati, Lavie, Singh, 2009; Reuer, Zollo, Singh, 2002). General collaborative experience refers to a focal firm's overall alliance experience in the previous years. Industry-specific alliance experience includes a focal firm's experience in only those alliances with other firms (i.e., partners) from a particular industry. Finally, partner-specific alliance experience entails a focal firm's learning with a specific partner at a dyadic level. The empirical evidence as to which of these types of experience leads to superior collaborative performance has been largely inconclusive (Gulati, Lavie, and Singh, 2009; Anand and Khanna, 2000; Dyer and Singh, 1998). 


\section{Alliance Experience Spill-Over to Acquisition}

Organizations learn from prior experience, and this learning is transferrable to accomplishing the same or related tasks in different contexts. One of the studies that contributed to understanding organizational learning in a multi-task setting was conducted by Zollo and Reuer (2010). They examined how, at a dyadic level of interorganizational partnership, organizational experience accumulated between partnering firms may influence the performance of another as the nature of the partnership changes. A valuable contribution of this study involves developing and testing a contingent theory of learning across organizational activities as alliance partners decide to pursue a deeper level of integration through acquisition. To understand the transfer of learning from the task of alliances to acquisitions, this study theorized that partner-specific alliance experience of a firm would be beneficial to the performance of the focal acquisition when an acquisition is managed in ways that resemble the typical handling of its alliances. However, when acquisitions are managed with more aggressive post-acquisition management approaches, the benefits of alliance experience can cease to work and can even adversely affect the acquisition performance.

Another recent study (Zaheer, Hernandez, and Banarjee, 2010) that integrated alliance activities and acquisition performance drew on the concept of absorptive capacity (Dyer and Singh 1998) as a pre-condition for weakening both pre- and postacquisition information asymmetry to understanding acquisition performance. This study, also at the dyadic level of partnership, postulated that partner-specific absorptive capacity is enhanced through prior alliance experience with targets and is particularly useful in 
ameliorating information asymmetry both in international acquisitions and knowledgeintensive acquisitions.

Yet another study by Agarwal et al. (2012) applied insights from organization design, economic game theory, and social psychology to emphasize the importance of prior resource allocation and communication in reducing behavioral uncertainty that arises in inter-unit coordination settings within and across organizations. This study's focus was to examine the extent to which routines created under one inter-organizational form (i.e., strategic alliances) at a dyadic level of relationship may be successfully transferred to another inter-organizational architecture (i.e., acquisition of a couple of alliance partners). This study particularly emphasized the importance of developing interorganizational social processes and norms for superior acquisition performance.

From a theoretical standpoint, previous studies have proposed that pre-acquisition alliance activities may enhance performance in an acquisition (Haspeslagh and Jemison, 1991; Kogut, 1991; Balakrishnan and Koza, 1993; Bleeke and Ernst, 1995; Hagedoorn and Sadowski, 1999; Porrini, 2004). However, the empirical evidence, thus far, is unable to provide a conclusive answer to the question as to which aspects of alliance experience contribute to performance differences. For instance, Higgins and Rodriguez (2006) reported a positive association between prior alliances on market reaction to acquisition announcements examining 160 pharmaceutical acquisitions, of which 28 percent had prior alliances. Whereas Zaheer et al. (2010) found no main effects of prior alliances between partners on their post-acquisition performance. Therefore, to extend our understanding based on this growing body of literature, we attempt to advance our theory beyond the dyadic view of experience spillover. More specifically, we examine the 
implications of organizational memory, routines, and relevance of learning from a focal acquirer's recent alliance experience in various contexts and with others firms to examine performance in this multi-task setting of transfer of learning.

It is apparent that researchers, to date, have mostly been interested in explaining benefits for organizational learning in alliances and acquisitions at the dyadic level of partnership. However, given the overall progress made by researchers at the program level of organizational learning, though separately in alliance and acquisition literature, in this study, we extend this literature of performance implications of transfer effects to the overall corporate and alliance $\&$ acquisition program level (as opposed to partner-specific learning) by integrating both of these streams of literature. Building on cognitive psychologists' assumptions, we argue that an organization's recent memory, commonality of elements, routines, and the context of learning in alliances may positively relate to enhanced performance in acquisitions.

\section{HYPOTHESES DEVELOPMENT}

Building on the above theoretical background, we theorize on developing the following hypotheses. An illustration of these hypothesized relationships is presented in the conceptual model of the study (Figure 3 - Study II): 


\section{Acquirer's Alliance Experience and Acquisition Performance}

Previous studies have widely speculated that post-acquisition performance may be improved by pre-acquisition alliance activity (Haspeslagh and Jemison, 1991; Bleeke and

Ernst, 1995; Hagedoorn and Sadowski, 1999). We develop this notion further by illustrating how a greater number of alliance experiences of an acquiring firm can enhance post-alliance acquisition performance: a) From a future target selection viewpoint, the number of prior alliance experiences may serve as an important screening technique for potential acquisition targets and have a positive performance effect (Kogut, 1991; Arend, 2004; Agarwal, Anand, Bercovitz, and Croson, 2012); b) consistent with the notion of "learning before doing" (Pisano, 1994), post-acquisition performance can be facilitated by the learning opportunity that firms may have due to their exposure to related and/or similar activities as they continue to cooperate in the post-acquisition organizational context; and c) due to the similarities between alliance and acquisition activities (Newburry and Zeira, 1997; Zeira and Newburry, 1999), numerous distinct processes and routines may be formed during alliance activities. These routines and learning may be applied to a post-acquisition context, which may enhance organizational efficiency in future acquisition integration processes and positively affect acquisition performance (Agarwal et al., 2012).

Whereas routine formation reinforces the experiential lessons learned from the routines and further adoption of a certain routine (March, 1981), the nature of prior organizational activities sets a more favorable stage for initial routinization and memory formation. When firms partner with organizations of different sizes, structures, purposes, and regions, the cumulative experience gained from these partnerships increases their breadth of future search, learning capabilities, and existing routines, thereby increasing their capabilities 
and efficiency (e.g., Jiang, Tao, and Santoro, 2010; Lavie, 2007; Reuer and Ragozzino, 2006; Goerzen and Beamish, 2005; Stuart, 2000). We believe that by engaging in a higher number of alliances, an acquirer can adeptly adjust its overall routines and processes and translate them into value enhancing systems for future acquisitions.

On the other hand, each time a firm's knowledge or learning is applied, opinions about the questions of "what works and why they work" are more firmly embedded in managerial cognition, thus routines become firmly established in an organization (Levitt and March, 1988; Nelson and Winter, 1982). Therefore, we believe that when alliance experience of a firm is insignificant, it may limit information processing and organizational search, which in turn may limit the creation of new routines and norms (Huber, 1991) for related organizational tasks - in this case acquisitions.

Vermeulen and Barkema (2001) argued that when differences in organizational tasks become too large (for instance, a company operates only in related industries or countries), it may ultimately hamper learning and a company may find it difficult to understand and interpret the different knowledge and routines and, as a consequence, will have problems absorbing and learning from other firms (Barkema, Shenkar, Vermeulen, and Bell, 1997; Huber, 1991; Lane and Lubatkin, 1998). Given that alliance/acquisition capability development, i.e., routines, memories, knowledge, processes, systems, structures, and skills, takes place primarily on the program level through a series of deals rather than from individual deals (Laamanen and Keil, 2008; Zollo, Reuer, and Singh, 2002), this process requires multiple alliance agreements for a firm to be able to build routines and draw correct inferences from previous tasks (Haleblian and Finkelstein, 1999). Therefore, we anticipate: 
Hypothesis 1 (H1): The higher the number of strategic alliances, the higher the

likelihood that the acquirer firm would have a superior acquisition performance.

\section{Acquirer's Alliance Experience in Target's Industry}

Cognitive psychologists have used a variety of technical terms to indicate transfer

effects in individual learning processes. Some of them have to do with the type of knowledge being transferred (e.g., motor or cognitive skills, declarative or procedural memory, etc.); the existence and strength of rules identifying the task (Holland et al. 1986); the existence, number, order, and type of cues or examples to refer to in the learning (Gick and Holyoak 1983, 1887; Cheng et al. 1986) and transfer processes (Reed et al. 1974, Hayes and Simon 1977); and the learner's background knowledge (Bransford and Franks 1976, Larkin et al. 1980).

A significant body of organizational learning literature has built on these notions of individual learning applied to the organizational level. Absorptive capacity (Cohen and Levinthal, 1990) is one such extension. Firms with high levels of absorptive capacity learn quickly from other firms and can develop routines that create economies of scale. Absorptive capacity refers to "the ability of a firm to recognize the value of new, external information, assimilate it, and apply it to commercial ends" (Cohen and Levinthal, 1990). Building on this premise, we argue that prior knowledge in a certain context (e.g., industry) can enhance the effects of learning from other related tasks.

Additionally, organizations are believed to have frames of reference, structures, routines, and physical artifacts that reflect knowledge retention (Moorman and Miner, 1997; Walsh and Ungson, 1991), which is conceptualized as organizational memory. At the 
individual as well as organizational levels, Anderson (1983) proposed that two types of memory are relevant to organizational learning: a) procedural memory as to how things are done (e.g., skills and routines) and b) declarative memory in terms of general memory for facts, events, material forms, and shared information (e.g., reports, summaries, agreements). We theorize that both of these memory types in alliances will facilitate acquisition performance. Procedural memory is particularly helpful since it is domain-dependent (Moorman and Miner, 1998), which is evidently the case for alliances in a particular industry. From the perspective of the content and level of organizational memory, a firm that has experience in a specific industry for some time will likely accumulate a high level of declarative memory about the competitive dynamics and detailed traits of the industry (Moorman and Miner, 1998) that they will be able to use in the acquisition context.

Given the interplay of absorptive capacity, organizational routines, and memory, we believe that an acquiring firm's alliance experience in a target's industry will likely benefit the acquirer's acquisition performance in a focal deal. We believe this occurs for the following reasons. First, though not in the same task (i.e., alliance vs. acquisition) or with the same partner (i.e., partner-specific learning), an acquirer's familiarity with alliance activities within a target firm's industry helps them to gain valuable prior knowledge and to develop organizational memory about similar businesses in the target firm's industry. Second, prior knowledge of the acquirer in a target firm's industry enables the acquirer to correctly assess a target firm's strengths and capabilities as a potential target (Wang and Zajac, 2007). Third, business similarity and industry knowledge help the acquirer to draw on previously established routines and collaborative processes that are specific to the target firm's industry and use them in the focal acquisition deal. Finally, the acquirer's level of prior industry 
knowledge facilitates building a post-acquisition relationship of mutual trust, communication, trust, and reciprocity that are critical for successful post-acquisition integration (Zaheer, McEvily, Perrone, 1998). Therefore, we predict the following relationship:

Hypothesis 2 (H2): An acquirer firm 's alliance experience in the target firm's industry is positively correlated with its acquisition performance.

\section{Acquirer's Alliance Experience in Target's Country}

Cohen and Levinthal (1990) argued that organizations need a level of preparedness, in other words, prior knowledge and absorptive capacity for effective transfer of prior experience. In this section, we continue to extend this argument of preparedness to the context of geographical preparedness for transfer of learning between tasks. We believe the level of preparedness is especially relevant in a multi-task transfer setting, because organizational ability to engage in effective learning is hindered when multiple parameters of the learning process are changed simultaneously (Teece, Pisano, and Shuen, 1997). A vast body of literature in international business and global strategy established that crossnational distance matters (Ghemawat, 2001). It particularly does so when it relates to inter-organizational exchanges where differences in norms, values, practices, rules, and policies result in a lack of contextual knowledge, liabilities of foreignness (Zaheer, 1995), breeding problems of communication, coordination, trust, and uncertainty.

Given this cross-national setting, in addition to declarative and procedural memory, we theorize on the implications of transactive memory (Wegner, 1986). Wegner proposed that encoding, storing, and retrieval of memory are facilitated by various types of interactions 
and transactions (hence the name) between and among group members in an organization. Oftentimes, labels and generalization by individuals play an important role in such transactive memory. We believe transactive memory is especially relevant in the context of cross-national inter-organizational exchange. Dyadic distance matters in an inter-organizational exchange process: higher geographic, economic, political, cultural, administrative, and psychic distance make it more difficult to impose the acquiring firm's dominant logic (Verbeke, 2010).

We propose that experience with international alliances, particularly partnerships with other firms in a target firm's country, is likely to be valuable in reducing the problems of liability of foreignness, information asymmetry in cross-national setting (Robson, Katsikeas, Bello, 2008; Balakrishnan and Koza, 1993), and issues of transactive memory building in a cross-national setting. Thus, we draw on prior research to suggest that familiarity with a target's home country, albeit in a different task, makes international acquisitions more successful. Whereas issues arising from information asymmetry and difficulties due to transactive memory in a cross-national setting increase the difficulties of pre-acquisition negotiation (Dikova, et al., 2010) and post-acquisition integration (Zander and Zander, 2010; Verbeke 2010), leading to an inferior acquisition performance. Therefore, we predict the following relationship:

Hypothesis 3 (H3): An acquirer firm's alliance experience in the target firm 's country is positively correlated with its acquisition performance. 


\section{Moderating Role of Acquirer's Acquisition Experience}

According to Thorndike (1903) and Tversky (1977), transfer of learning in a multitask setting may occur when learning in one context/task enhances (positive transfer) or undermines (negative transfer) performance in another related context/task. Transfer of learning may also take different forms: near transfer (to closely related contexts /tasks) and far transfer (to rather different contexts /tasks) (Perkin and Salomon, 1992). Gagne (1966) used a skill hierarchy to distinguish between lateral (transfer between different tasks) and vertical (transfer between lower and higher level skills) transfer of learning. We believe that transfer of learning from alliance experience to acquisition performance is a case both of lateral (due to the difference in alliance and acquisition activities) and vertical transfer (from collaborative relationship to increased interdependency and resource commitment in acquisitions).

Alliances and acquisitions, though the two alternative governance structures share commonality (Wang and Zajac, 2007; Zeira and Newburry, 1999), thus are considered two different corporate activities. Their similarities can be perceived in an organization's search for alliance/acquisition partners, negotiation and evaluation of the deal, and post-deal organization and coordination (Zollo and Reuer, 2010). More importantly, at the corporate level, both of these activities are commonly managed by the same department, which is critical to firm-level learning. Despite these similarities, alliances and acquisitions also have several differences that may complicate the transfer of learning when firms implement acquisitions relying on their prior alliance experiences. Alliances and acquisitions are alternative governance structures requiring different levels of control and coordination (Wang and Zajac, 2007). From a deal-making standpoint, these activities also differ since acquisitions tends to be characterized by a much more formal and 
extensive due diligence (Zollo and Reuer, 2010). On the other hand, alliance structures tend to be more transitional in nature (Phene and Tallman 2012; Reuer, Zollo, and Singh, 2002; Ariño and De La Torre, 1998; Doz and Hamel, 1998), involving a co-evolution of trust, control, and learning (Inkpen and Currall 2004). Notwithstanding these differences, a case has been made in the literature that past alliance experiences might be sufficiently similar in the dimensions of task, process, or context to some acquisitions to influence the latter's performance. Therefore, positive experience spillovers may occur due to the similarity between alliance (learned activity in one task) and acquisition activities (the one to which learning is applied) (Thorndike, 1903; Tversky, 1977).

Considering both the similarities and differences in alliances and acquisitions, we argue that an acquirer's acquisition related memory, routines, capabilities, etc. will enhance its learning from alliance activities. Therefore, we expect an interaction between an acquirer's prior acquisition experience and alliance experience in predicting the relationship between alliance experience and subsequent acquisition performance:

Hypotheses 4 (H4): An acquirer's acquisition experience will positively moderate the following relationships between:

(H4a) acquirer's alliance experience and acquisition performance, such that the positive relationship will be strengthened by the acquirer's recent acquisition experience.

(H4b) acquirer's alliance experience in target firm's industry and acquisition performance, such that the positive relationship will be strengthened by the acquirer's recent acquisition experience. 
(H4c) acquirer's alliance experience in target firm 's country and acquisition performance, such that the positive relationship will be strengthened by the acquirer's recent acquisition experience.

\section{METHODOLOGY}

A detailed description of the sample, data sources, variables, and measures used to empirically test the hypotheses of the study are provided in the following section:

\section{Sample and Data Sources}

Data on alliance and mergers \& acquisitions (M\&A) announcements were extracted for the years 1990-2012. The initial sample consisted of all the entries of alliances and M\&As compiled from Security Data Corporation (SDC) Platinum database's M\&A and joint-venture modules. The initial sample included all the alliance deal announcements during 1991-2010 and M\&A announcements during 1991-2012. Next, from the M\&A sample, for hypotheses testing, due to availability of data for the US firms, we included only those firms that come from US origin and furthermore, those cases where acquisitions were actually completed. In other words, we are interested in only those acquisitions that are initiated and completed by US firms within years 1994 and 2010. Though the data is available prior to 1994, acquisitions until 1994 were excluded since we had to measure the alliance experience variable which is based on 4 years data prior to the focal acquisition and since this set of data starts from 1991. Finally, we complemented our data, by extracting a number of financial variables (e.g., ROE) from the Compustat database. 


\section{Measures}

\section{Dependent Variable}

Acquisition Performance: Acquisition performance attempts to capture the superiority of a firm's ex post financial performance, given the event of a completed acquisition. We used accounting based measures to calculate an acquiring firm's performance from a focal acquisition. Consistent with Zollo and Reuer (2010) and Meeks and Meeks (1981), we used a measure capturing the change in return on equity of a focal acquiring firm following a completed acquisition. In other words, performance was measured as the difference between the return on equity (ROE) of the acquiring firm two years after the acquisition relative to one year prior to the acquisition.

An alternate method to measure acquisition performance is to use a cumulative abnormal returns (CAR) value given an M\&A announcement. It is an ex ante marketbased proxy for actual returns based on the stock market reactions given the announcement of an M\&A event. Researchers using this event-study method have used a variety of a short to a long window ranging from 7 days to 241 days around an acquisition announcement (e.g., Zaheer, et al., 2010; McNamara, Haleblian, and Dykes, 2008; Haleblian, Kim, and Rajagopalan, 2006). While CAR is one of the most widely used measures for capturing M\&A performance, it has some major drawbacks. First, the subjective judgment of the researcher in terms of using a small/medium/long window opens the interpretation of the results for criticism. Second, since event-study method entails using the collective response of stock market investors regarding the potential performance implications of an M\&A, it works as a proxy rather than gauging the actual performance effects of an M\&A. 
To address these potential issues with event-study methods, following Kim and Finkelstein (2009) and Zollo and Reuer (2010), we opted to use an accounting based measure for this variable, e.g., ROE extracted from the Compustat database. Additionally, we chose ROE over the measure of return on assets (ROA) since our sample includes both service (low fixed asset) and manufacturing (high fixed asset) type firms.

\section{Explanatory Variables}

Acquirer's Recent Alliance Experience (H1): To observe the performance implications of organizational routines and learning accumulate from recent alliance experience of an acquiring firm, we created a measure of recent alliance experience by capturing an acquiring firms' alliance deals. The underlying assumption is that with every alliance deal, a future acquirer develops valuable insight and routines (Gulati, Lavie, Singh, 2009; Zollo, Reuer, and Singh, 2002), and building on related routines, acquiring firms gain superior acquisition performance (Haleblian, Kim, and Rajagopalan, 2006). However, as we discussed in the theoretical background section of this paper, recency is an important dimension to the relevance of experience and routines (Zollo and Reuer, 2010; Ingram and Simons, 2002; Ingram and Baum 1997; Argote and Epple, 1990).

To operationalize this variable, we track the acquiring firms' number of alliances deals prior to a focal acquisition attempt. In this case, the focal acquirer firm is the one that completes an acquisition attempt. Furthermore, our alliance experience variable is calculated based on the number of cross-border alliances completed by a focal acquirer within 4 years prior to the focal acquisition. 
Acquirer's Alliance Experience in Target's Industry (H2): This variable

attempts to capture a focal acquirer's partnering experience in a specific industry that may be applicable to a future acquisition. This variable is an ordinal variable representing the number of alliances an acquiring firm had in the same industry, as differentiated by the SIC codes of the target firm's industry within 4 years prior to the focal acquisition. To operationalize this variable, we created a new variable based on the number of alliance partnerships by searching the specific windows of alliance data given the announcement date of a focal acquisition. According to Schilling (2009), of the most popular alliance databases, the SDC Platinum covers the widest range of industry sectors between 1985 and 2005. We used Standard Industrial Classification (SIC) codes to denote industry specific alliance experience consistent with Anand and Khanna (2000) and Jiang, Tao, and Santoro (2010).

Acquirer's Alliance Experience in Target's Country (H3): Similar to the previous explanatory variable, this variable is intended as a proxy of the acquirer's routines and experience in particular country that may be applied to enhance future acquisition performance in the same national context. This variable is also an ordinal variable representing the number of alliances an acquiring firm had in the same nation of its target in the focal acquisition. This is measured by taking into account alliance participants' primary nation codes in the alliance deals that were completed within 4 years prior to the focal acquisition. According to Schilling (2009), of the all-sector datasets, SDC Platinum appears to be the most inclusive in terms of types of nations (as denoted by participants' nation codes) represented. We used participants' two digit nation codes to capture an acquiring firm's country specific alliance experience. 
Acquirer's Acquisition Experience (H4): This variable captures an acquiring firm's experience, organizational memory, and routines developed from recent acquisition deals. Although acquisition experience is not a direct measure of organizational learning, it has been extensively used in the literature as a proxy, and can be reasonably expected to yield a strong positive correlation between the number of previous acquisitions and development of acquisition capabilities and routines (Zaheer, et al., 2010). We measure this ordinal variable by taking into account the frequency of prior acquisition deals completed by an acquirer firm within 4 years prior to the focal deal (Zaheer et al., 2010; Haleblian, Kim and Rajagopalan, 2006; Hayward, 2002; Argote and Epple, 1990).

\section{Control Variables}

Several decades of work on understanding acquisition performance identifies numerous firm-, industry-, country-, and deal-specific variables that may relate to an acquirer's superior performance. In addition to the main predictor variables described above, to address the acquiring firm's resources and possible confounding effects of other acquisitions on accounting or financial returns, we used the following control variables in our model:

Acquiring Firm's Characteristics:

a) Acquirer Size (CV1): We used a proxy for an acquirer's size; measured as the logarithm of the acquiring firm's total assets in billions of dollars for the year before the acquisition event (Zollo and Reuer, 2010; Haleblian et al., 2006).

b) Acquirer's debt to equity ratio (CV2) to proxy for the availability of financial resources available to the acquiring firm. 


\section{Target Firm's Characteristics:}

c) Characteristics of the target firm should also influence acquisition outcomes.

We theorized in the hypotheses development section that international acquisition strategies involve an inherent liability of foreignness (Zaheer 1995). Thus, cross-border targets are particularly difficult to evaluate prior to acquisition and integrate postacquisition. We control for this possibility of Foreign Targets (CV3) through a binary variable. If the target firm is from the United States then it is coded as 1 , and 0 otherwise.

d) Since our sample includes both publicly traded and privately owned target firms, to enhance the generalizability of our findings, we included a variable as to whether the target is a Public Target (CV4), coded as 1 if the target is publicly listed and 0 otherwise (Dikova et al., 2010; Zaheer, et al., 2010).

Deal Characteristics:

We also used a number of deal specific control variables:

e) Acquisition Deal Attitude (CV5): Hostile and competitive acquisitions invoke various types of pre-acquisition and post-integration resistance from the target firm's management. If the deal attitude is friendly we coded this variable to be 1 , otherwise, 0 .

f) Relative size (CV6) of the target and acquirer: Prior studies have provided ample evidence that the relative sizes of a target and an acquirer affect acquisition outcomes. This variable is calculated as the ratio of a target firm's total assets and an acquiring firm's total assets (Haleblian, et al., 2006).

Finally, we used binary variables to control for differences in year specific and industry-based (SIC codes) market variations. We then analyzed the data using ordinary least squares (OLS) regression analysis. 


\section{RESULTS AND DISCUSSION}

The descriptive statistics, i.e., mean, standard deviations, and bivariate correlation estimates for our measures are presented, respectively, in Table 1 and Table 2. Evaluation of the correlation matrix reveals that there are no significantly high correlations among the variables of the study that could confound results due to multicollinearity leading to variance inflation. Our results made it evident that among the explanatory and the control variables, none of the variance inflation factors (VIF) exceeded the conventionally followed cutoff limit of 10 (Kutner, Nachtsheim, and Netter, 2004; Kleinbaum, Kupper, and Muller, 1988). More specifically, the VIF estimates of all the variables used in our study were below 9.85 , suggesting that there was no significant threat of multicollinearity in our model.

Table 3 presents the results of OLS regression analyses applied to test each of the hypotheses involving the change in accounting performance of the focal acquirer. Model I is a baseline specification that includes all of the control variables, Model II incorporates acquiring firm's alliance experience terms, and Model III and IV include acquirer's prior alliance experience in target's industry and experience in target's nation, respectively. Furthermore, Model $\mathrm{V}$ introduces the moderating variables, i.e., acquiring firm's acquisition experience and its interactive effects in the same equation with the previously included independent variables to test the three baseline hypotheses.

In the first hypothesis, we anticipated that prior and recent alliance experience of an acquirer will positively relate to its acquisition experience. The empirical analyses 
provided no statistically significant support for the hypothesized effects of indicating that recent alliance experience of the acquirer has no direct, linear effect on the change in return on equity (ROE) of the acquirer. In other words, organizational learning at the alliance program level may not have any substantial implications for acquisition performance. In the second hypothesis, we predicted that an acquirer's prior alliance experience in a future target's industry will positively be associated with its change in ROE over a window of 3 years. We did not find a statistical support for H2. Both of these hypotheses were built on the arguments of declarative and procedural memory.

Our third hypotheses expected a positive association between an acquirer's prior alliance experience in the target's firm's country location and its superior acquisition performance. This hypothesis drew on the arguments of the difficulties of interorganizational interactions and transactions at a cross-border setting. Consistent with our arguments, we find statistical significance in favor of $\mathrm{H} 3(\mathrm{p}<0.05)$. The results underscore the importance of country specific transactive memory, albeit in an alliance context, for the improvement of acquisition performance.

In light of the arguments on the relatedness between the task and processes of alliances and acquisitions, we made several predictions involving acquirer's prior acquisition experience at the program level. Contrary to our expectations and previously conducted studies, H4 was not found statistically significant for our sample of US acquirers. This suggested a lack of association between acquirer's prior and recent acquisition experience and enhanced acquisition performance. In addition, when we tested for the moderating role of an acquirer's prior acquisition experience on the initially 
stated relationship in our baseline hypotheses concerning various types of alliance experience and acquisition performance, we find some support.

In view of the moderator, quite contrary to prior findings on acquirer acquisition experience, in the full and final model (Model IV) we find no statistical support for the main effect of this variable for acquisition performance. However, we found that it interacts with industry- and nation-specific prior alliance experience, albeit in the direction contrary to our expectation. However, considering the directionality of our prediction we did not find statistical support for $\mathrm{H} 4 \mathrm{a}, \mathrm{H} 4 \mathrm{~b}$, and $\mathrm{H} 4 \mathrm{c}$. In all three of the cases, the interaction terms supported a negative association with our dependent variable. This confirms a weakening effect of acquirer's acquisition experience on the positive relationship between prior industry- and nation- related alliance experience. Possible explanation for this inconsistency may be attributable to the ideas that managers of acquiring firms: a) may either be falling into "competency traps" by acting rather aggressively while making meaning of their prior related experience in two related, yet different tasks, and/or, b) may not be recognizing the underlying differences in alliances and acquisitions, and are over-generalizing while applying their routines and learning in two different contexts.

The overall results of our analyses empirically support our overarching theoretical arguments. Specifically, the analyses offer general support for our hypotheses that drew on how various types of declarative, procedural, and transactive dimensions of organizational memory determine the transfer of learning given some relatedness and difference of tasks in an inter-dependent setting. In both of these cases, we found no support for the hypotheses $\mathrm{H} 4 \mathrm{a}, \mathrm{H} 4 \mathrm{~b}$, and $\mathrm{H} 4 \mathrm{c}$ ). 
In line with findings in previous studies on prior alliance experience, we were unable to find empirical support for the relationship between general alliance experience and acquisition experience, even after considering only the recent experience. But, interestingly, and consistent with our prediction, the results confirm the relevance of related experience in industry and national contexts for facilitating the transfer effects of learning in a multi-task setting. One possible explanation for the inconsistency in our predictions and empirical findings for the unsupported hypotheses may be attributable to the arguments that managers of acquiring firms: a) may be falling into "competency traps" and aggressively applying their prior alliance experience related experience during post-acquisition phase which, albeit similar, requires a vast set of skills and experience due to the post-acquisition integration, and/or, b) may not be recognizing the underlying differences in alliances and acquisitions, and are erroneously over-generalizing based on their learning in alliances to apply their routines in an acquisition context.

More importantly, empirical results for the $\mathrm{H} 3$ supports the explanation that related prior experience, routine, and preparedness in targets' country context developed though an acquirer's recent alliance experience beyond partner/target-specific experience, help to create certain types of useful memory to facilitate a superior acquisition performance. This finding adds further explanations to the vast body of literature that examines acquisition success/failure. It also extends the streams of literature on alliance portfolio and acquisition program perspective that explain performance outcomes of these activities in a cross-form setting of organizational learning. 


\section{LIMITATIONS AND IMPLICATIONS}

Like any other study, ours has a number of limitations which, if carefully crafted, may be addressed in future endeavors. For instance, we did not explicitly measure postformation management processes in the context of alliances or acquisitions. Future research could improve upon this, also incorporating other dimensions that can affect the transfer process such as decision-making speed, the structure of project management teams, communication processes, and so forth to compare both the tasks of alliance and acquisition. In addition, since we focus on announced deals based on publicly available data, we are unable to capture the actual routine involved in the process. As a result, drawing on previous empirical studies, we used a number of proxies to operationalize our variables. Further studies using case-based and survey-based method may provide further understanding of these learning outcomes. As with other well-published studies, despite the prevalent use and richness of SDC Platinum database for strategic alliance research, our empirical results may be somewhat limited by occasional coding error given the reporting standards and availability of data points (Schilliing, 2009). Furthermore, we used only accounting based measures to quantify acquisition performance. Future studies may use an ex ante performance measure (CAR) from the stock market reactions to further support the results. Given the inconclusive evidence in favor of the relevance of acquirer's prior alliance experience for acquisition performance, it may make sense to explore various characteristics of alliances (e.g., depth, breadth, or patterns of alliance formation) to further examine this relationship between alliance experience and acquisition performance. Lastly, the results of this study should be generalized with caution, since our sample includes completed acquisitions by only US firms. 
Our results have three broad managerial implications. First, our empirical results generally confirm that a future acquirer's prior involvement in specific types of strategic alliances can enhance its acquisition performance. In other words, a generalized corporate development capability (Zaheer et al., 2010; Zollo and Reuer, 2010) may not ensure a positive experience spillover between alliances and acquisitions in general. However, from an information-processing and specialization standpoint, decision-makers of a firm would greatly benefit from relevant alliance experience, given certain learning conditions are met. For instance, alliance experience can be particularly helpful for the success of acquisitions in some well-defined and familiar contexts (i.e., in certain industries and nations) as we identify. Second, our results suggest that managers would benefit if they complement their experience in on task (alliances) by drawing on their experience in other related tasks (acquisitions), especially when the contexts of learning are similar to encourage positive transfer effects of learning. In other words, managers need to be careful of inadvertently or inappropriately generalizing from prior alliance experiences to the management of their acquisition activities.

\section{CONTRIBUTION}

Overall, this study attempted to contribute to corporate development activities literature by theorizing on the implications of experience, memory, routine, and learning in a multi-task and interdependent learning context. Building on recent studies (Zollo and Reuer, 2010; Zaheer, Hernandez, and Banerjee, 2010; Agarwal, Anand, Bercovitz, and Croson, 2012) that integrated the research streams of alliance and acquisition activities, we attempted to inform our understanding of acquisition performance by theorizing on the 
dimensions of memory and learning mechanisms that are mutually inclusive for the tasks of alliance and acquisition. Since extant studies investigated acquisition-related properties and alliance properties at the dyad level result in superior acquisition performance, we contribute to this research stream by considering the effects of accumulated learning in related tasks and contexts for superior performance in a cross-form setting. In other words, we particularly highlighted the importance of the relevance and the elements of learning (Thorndike 1960; Gagne, 1966) at the alliance program level (i.e., cumulative learning from alliance). This enables us to recognize how experience gained in a firm's alliance portfolio may positively relate to a focal firm's acquisition performance. Therefore, this study makes the following contributions:

a) Developing a further expansive theory regarding understanding the effective management of acquisitions.

b) Recognizing that given certain dimensions of relatedness, organizational learning based on the alliance program/portfolio is transferrable in a multi-task setting.

c) Emphasizing the relevance of procedural, declarative, and transactive memory dimensions (Thorndike 1960; Gagne, 1966) for a superior transfer effect of learning in a multi-task setting.

d) Underscoring the depth, e.g., specialization of learning, exploitation matters greatly to learning spillovers across corporate activities, especially when complemented by breadth, e.g., diversity of learning, exploration (March, 1991, Rothaermel and Deeds, 2004). 


\section{DISSERTATION CONCLUSION}

With a view to understand the interdependencies of corporate-level strategic activities, this dissertation took an integrative approach and conducted two empirical studies synthesizing alliance and acquisition research. Study I analyzed alliance and acquisition research using a relational and dyadic framework to understand the corporate strategy of

future target selection. Study II integrated alliance portfolio research and acquisition program perspectives for a organizational level of analysis vis-à-vis an activity based learning to examine corporate-level acquisition performance. Overall, this dissertation attempted a step toward taking stock of a vast body of extant research in two parallel streams to extend our understanding from a broader corporate development perspective. As the field of strategic management matures, given last 5 decades of rich scholarship, this new domain of crossstream studies promises to open further avenues of research for a holistic understanding of multinational corporations' strategy and performance. 


\section{REFERENCES (STUDY - I)}

Almeida P, Phene A. 2004. Subsidiaries and knowledge creation: the influence of the MNC and host country on innovation. Strategic Management Journal, Special Issue 25(8-9): 847-864.

Anand, B., T. Khanna. (2000). Do firms learn to create value? The case of alliances. Strategic Management Journal, 21(3) 295-315.

Arend R.J. (2004). Conditions for asymmetric information solutions when alliances provide acquisition options and due diligence. Journal of Economics, 82 (3) 281312.

Balakrishnan S, Koza MP. 1993. Information asymmetry, adverse selection and joint ventures: theory and evidence. Journal of Economic Behavior and Organization 20: 99-117.

Barkema HG, Shenkar O, Vermeulen F, Bell JHJ. 1997. Working abroad, working with others: how firms learn to operate international joint ventures. Academy of Management Journal 40(2): 426-442.

Barney JB. 1986. Strategic factor markets: expectation, luck, and business strategy. Management Science. 32(10): 1231-1241.

Barney, J. B. (1991). Firm resources and sustained competitive advantage. Journal of Management, 17(1): 99-121.

Bleeke, J., Ernst, D. (1995). Is your strategic alliance really a sale? Harvard Business Review, 97-105.

Bowman, E. H., D. Hurry. 1993. Strategy through the option lens: An integrated view of resource investments and the incremental choice process. Academy of Management Review. 18(4) 760-782.

Burt, R. 1992. The social structure of competition. N. Nohria, R. Eccles, eds. Networks and Organizations: Structure, Form and Action. Harvard University Press, Boston, 57-91.

Cohen WM, Levinthal DA. 1990. Absorptive capacity: a new perspective on learning and innovation. Administrative Science Quarterly 35(1): 128-152.

Cote, L., Langley, A., Pasquero, J. 1999. Acquisition strategy and dominant logic in an engineering firm. Journal of Management Studies, 36(7): 919-952.

Cuypers, I., Martin, X. 2010. What makes and what does not make a real option? A study of equity shares in international joint ventures. Journal of International Business Studies, 41(1): 47-70. 
Dussauge, P., Garrette, B., and Mitchell, W. (2000). Learning from competing partners: Outcomes and durations of scale and link alliances in Europe, North America and Asia. Strategic Management Journal 21(2): 99-126.

Dikova, D., Sahib, P.R., Witteloostuijn, A.V. (2010). Cross-border acquisition abandonment and completion: The effect of institutional differences and organizational learning in the international business service industry,1981-2001. Journal of International Business Studies, 41, 223-245

Dyer JH, Singh H. 1998. The relational view: cooperative strategy and sources of interorganizational competitive advantage. Academy of Management Review $23: 660-679$.

Eisenhardt, K. M. and Schoonhoven, C. B. (1996). Resource-based view of strategic alliance formation: strategic and social effects in entrepreneurial firms. Organization Science, 7, 2, 136-50

Finkelstein, S, Haleblian, J. 2002. Understanding acquisition performance: the role of transfer effects. Organization Science, 13(1): 36-47.

Garette, B., P. Dussauge. 2000. Alliances versus acquisitions: Choosing the right option. European Management Journal. 18(1) 63-69.

Gomes-Casseres B. 1987. Joint venture instability: is it a problem? Columbia Journal of World Business. 22:97-102.

Greve H.R. 2003. A behavioral theory of R\&D expenditures and innovation: evidence from shipbuilding. Academy of Management Journal. 46: 685-702.

Grant RM. 1996. Prospering in dynamically-competitive environments: organizational capability as knowledge integration. Organization Science 7: 375-387.

Grant RM, Baden-Fuller C. 2004. A knowledge accessing theory of strategic alliances. Journal of Management Studies 41: 61-84.

Gulati, R. (1999). Network location and learning: The influence of network resources and firm capabilities on alliance formation. Strategic Management Journal, 20(5), 397.

Gulati R. 1995. Does familiarity breed trust? The implications of repeated ties for contractual choice in alliances. Academy of Management Journal. 38:85-112.

Gulati, R., D. Lavie, H. Singh. 2009. The nature of partnering experience and the gains from alliances. Strategic Management J.30(11) 1213-1233. 
Gulati R, Singh H. 1998. The architecture of cooperation: managing coordination costs and appropriation concerns in strategic alliances. Administrative Science Quarterly 43(4): 781-814.

Gulati R, Wang LO. 2003. Size of the pie and share of the pie: implications of structural embeddedness for value creation and value appropriation in joint ventures. Research in the Sociology of Organizations 20: 209-242.

Gulati R, Sytch M. 2007. Dependence asymmetry and joint dependence in interorganizational relationships: effects of embeddedness on exchange performance. Administrative Science Quarterly 52: 32-69.

Gulati R, Sytch M. 2008. Does familiarity breed trust? Revisiting the antecedents of trust. Managerial and Decision Economics 29: 165-190.

Gulati R, Sytch M, Mehrotra P. 2008. Breaking up is never easy: planning for exit in a strategic alliance. California Management Review. 50(4): 147-163.

Haleblian J, Finkelstein S. (1999). The influence of organizational acquisition experience on acquisition performance: a behavioral learning perspective. Administrative Science Quarterly, 44(1): 29-56.

Haleblian, J., Kim, J., and Rajagopalan, N. (2006). The influence of acquisition experience and performance on acquisition behavior: Evidence from the U.S. commercial banking industry. Academy of Management Journal, 49: 357-370.

Harrison JS, Hitt MA, Hoskisson RE, Ireland RD. 2001. Resource complementary in business combinations: extending the logic to organizational alliances. Journal of Management 27(6): 679-690.

Haspeslagh, P., D. Jemison. 1991. Managing Acquisitions: Creating Value Through Corporate Renewal. Free Press, New York.

Hogarth, R. M., and Einhorn, H. J. 1992. Order effects in belief updating: The belief adjustment model. Cognitive Psychology, 24: 1-55.

Inkpen, A. (1998). Learning, knowledge acquisition, and strategic alliances. European Management Journal. 16(2) 223-229.

Jiang, R.J., Tao, Q.T, Santoro, M.D. 2010. Alliance portfolio diversity and firm performance. Strategic Management Journal, 31: 1136-1144

Inkpen, A.C. and Tsang, E.W.K. (2005) Social capital, networks, and knowledge transfer. Academy of Management Review, Vol. 30 No. 1, pp. 146-65. 
Kale, P., J. Dyer, H. Singh. 2002. Alliance capability, stock market response, and longterm alliance success: The role of the alliance function. Strategic Management $J$. 23(8) 747-767.

Kale, P., H. Singh, H. Perlmutter. (2000). Learning and protection of proprietary assets in strategic alliances: Building relational capital. Strategic Management Journal, 21(3) 217-237.

King, D. R., Dalton, D. R., Daily, C. M., \& Covin, J. G. (2004). Meta-analyses of postacquisition performance: Indications of unidentified moderators. Strategic Management Journal, 25(2), 187-187+.

Kleinbaum, D.G., Kupper, L.L., \& Muller, K. E. 1988. Applied regression analysis and other multivariable methods. PWS Publishing: Boston, MA.

Kogut, B. (1991). Joint ventures and the option to expand and acquire. Management Science. 37(1)19-33.

Kostova, T., \& Zaheer, S. (1999). Organizational legitimacy under conditions of complexity: The case of the multinational enterprise. Academy of Management Review, 24(1): 64-81.

Krug, J. A., \& Hegarty, W. H. 2001. Predicting who stays and leaves after an acquisition: A study of top managers in multinational firms. Strategic Management Journal, 22(2):185-196.

Kutner, M., Nachtsheim, C., Neter, J. 2004. Applied Linear Regression Models, 4th edition, McGraw-Hill Irwin.

Lane P.J. and Lubatkin M.H.. (1998). Relative absorptive capacity and interorganizational learning. Strategic Management Journal 19(5): 461-477.

Lane, P. J., J.E. Salk, M. A. Lyles. 2001. Absorptive capacity, learning, and performance in international joint ventures. Strategic Management J. 22 1139-1161.

Lavie D, Miller S. 2008. Alliance portfolio internationalization and firm performance. Organization Science, 19(4): 623-646.

Lorenzoni G, Lipparini A. 1999. The leveraging of interfirm relationships as a distinctive organizational capability: a longitudinal study. Strategic Management Journal 20(4): 317-338.

Levitt, B., \& March, J. G. (1988). Organizational learning. In W. R. Scott (Ed.), Annual review of sociology, vol.14: 319-340. Palo Alto, CA: Annual Reviews.

Lindblom, C. E. 1959. The "science" of muddling through. Public Administration Review, 19:79-88 
March J.G., Simon H. 1958. Organizations. Wiley: New York.

Merchant H, Schendel D. 2000. How do international joint ventures create shareholder value. Strategic Management Journal 21(7): 723-737.

Meyer, C. B., \& Altenborg, E. (2008). Incompatible strategies in international mergers: The failed merger between Telia and Telenor. Journal of International Business Studies, 39(3): 508-525.

Morosini, P., Shane, S., \& Singh, H. (1998). National cultural distance and cross-border acquisition performance. Journal of International Business Studies, 29(1): 137-159.

Miller, D., \& Friesen, P. H. (1980) Momentum and revolution in organization adaptation. Academy of Management Journal, 23, 591-614.

Nanda, A., and Williamson, P. J. (1995). Use Joint Ventures to Ease the Pain of Restructuring. Harvard Business Review 73(6): 119-128.

Nelson, R. R., \& Winter, S. G. (1982). An evolutionary theory of economic change. Cambridge, MA: Harvard University Press.

North, D. (1990). Institutions, institutional change and economic performance. Cambridge: Cambridge University Press.

Olsen, J. P. 1976. The process of interpreting organizational history. In Ambiguity and Choice in Organizations, ed. J. G. March, J. P. Olsen, pp. 338-50. Bergen, Norway: Universitetsforlaget.

Park, S. H., and Kim, D. (1997). Market Valuation of Joint Ventures: Joint Venture Characteristics and Wealth Gains. Journal of Business Venturing 12(2): 83-108.

Park, S. H., and Russo, M. V. (1996). When Competition Eclipses Cooperation: An Event History Analysis of Joint Venture Failure. Management Science 42(6): 875-890.

Park, S. H., and Ungson, G. R. (1997). The effect of national culture, organizational complementarity and economic motivation on joint venture dissolution. Academy of Management Journal 40: 279-307.

Parkhe A. 1993. Strategic alliance structuring: a game theoretic and transaction cost examination of interfirm cooperation. Academy of Management Journal 36(4): 794-829.

Peng, MW, Wang, D, Jiang, Y. (2008). An institution-based view of international business strategy: a focus on emerging economies. Journal of International Business Studies 39: 920-936. 
Penrose, E. (1959). Theory of the Growth of the Firm. Oxford: Blackwell.

Pfeffer, J. and Salancik, G.R. 1978. The External Control of Organizations: A Resource Dependence Perspective. New York: Harper and Row. Radcliffe-Brown, A. R.

Phene A., Almeida P. 2008. Innovation in multinational subsidiaries: The role of knowledge assimilation and subsidiary capabilities. Journal of International Business Studies. 39, 901-919

Phene, A., Tallman, S. 2012. Complexity, context and governance in biotechnology alliances. Journal of International Business Studies. 43, 61-83

Reuer JJ. 2000. Parent firm performance across international joint venture life-cycle stages. Journal of International Business Studies. 31: 1-20.

Reuer J.J., Koza MP. 2000. Asymmetric information and joint venture performance: theory and evidence for domestic and international joint ventures. Strategic Management Journal 21(1): 81-88.

Reuer, J. J., \& Zollo, M. (2005). Termination outcomes of research alliances. Research Policy, 34(1), 101-115.

Reuer, J. J., Zollo, M., \& Singh, H. (2002). Post-formation dynamics in strategic alliances. Strategic Management Journal,23(2), 135-151.

Reuer, J., \& Zollo, M. (2000). Managing governance adaptations in strategic alliances. European Management Journal, 18(2), 164-172.

Rothaermel, F. T. (2001). Incumbent's advantage through exploiting complementary assets via interfirm cooperation. Strategic Management Journal, 22, Summer special issue, 687-99.

Santoro MD, Chakrabarti A. 2002. Firm size and technology centrality in industryuniversity interactions. Research Policy 31(7): 1163-1180.

Sarkar, M., P. S. Aulakh, A. Madhok. (2009). Process capabilities and value generation in alliance portfolios. Organization Science, 20(3) 583-600.

Scott, R. (1995). Institutions and organizations, Thousand Oaks, CA: Sage.

Siegel, S. 1957. Level of aspiration and decision making. Psychology Review. 64:253-62

Simon, H. A. 1955. A behavioral model of rational choice. Quarterly Journal of Economics. 69:99-118

Simonin BL. 1997. The importance of collaborative know-how: an empirical test of the learning organization. Academy of Management Journal 40(5):1150-1174. 
Sirower, M.L. (1997). The synergy trap: How companies lose the acquisition game. New York: Free Press.

Steinbruner, J. D. 1974. The Cybernetic Theory of Decision. Princeton, NJ: Princeton University Press

Steiner, D. D., and Rain, J. S. 1989. Immediate and delayed primacy and recency effects in performance. Journal of Applied Psychology, 74: 136-142.

Szulanski G. 1996. Exploring internal stickiness: impediments to the transfer of best practice within the firm. Strategic Management Journal, Winter Special Issue 17: $27-44$.

Tallman, S. and A. Phene. 2007. Leveraging knowledge across geographic boundaries, Organization Science, 2007, 18(2): 252-260

van de Ven, A. H. and Walker, G. (1984). The dynamics of interorganizational coordination. Administrative Science Quarterly, 29, 598-621.

Verbeke, A. (2010). International acquisition success: Social community and dominant logic dimensions. Journal of International Business Studies, 41(1), 38.

Verbeke, A., \& Kenworthy, T. 2008. Multidivisional versus metanational governance of the multinational enterprise. Journal of International Business Studies, 39(2): 940-956.

Wang, L., \& Zajac, E. J. (2007). Alliance or acquisition? A dyadic perspective on interfirm resource combinations. Strategic Management Journal, 28(13), 1291.

Wernerfelt B. 1984. A resource-based view of the firm. Strategic Management Journal. 5(2): 171-180.

Weber, Y., Shenkar, O., \& Raveh, A. 1996. National and corporate cultural fit in mergers/acquisitions: An exploratory study. Management Science, 42(8): 12151227.

Williamson OE. 1985. The Economic Institutions of Capitalism. Free Press: New York.

Yan, A. 1998. Structural stability and reconfiguration of international joint ventures. Journal of International Business Studies 29: 773-795.

Zaheer, A., Hernandez, E., Banerjee, S. (2010. Prior Alliances with Targets and Acquisition Performance in Knowledge-Intensive Industries. Organization Science 21(5) 1072-1091. 
Zaheer A, McEvily B, Perrone V. 1998. Does trust matter? Exploring the effects of interorganizational and interpersonal trust on performance. Organization Science. 9(2): 141-159.

Zollo, M., \& Reuer, J. J. (2010). Experience spillovers across corporate development activities. Organization Science, 21(6), 1195-1212,1275-1276.

Zollo, M., Reuer, J. J., \& Singh, H. (2002). Interorganizational routines and performance in strategic alliances. Organization Science, 13(6), 701-713. 


\section{REFERENCES (STUDY - II)}

Agarwal, R., Anand, J., Bercovitz, J., Croson, R. (2012). Sprillovers across organizational architectures: The role of prior resource allocation and communication in post-acquisition coordination outcomes. Strategic Management Journal, 33: 710-733

Anand, B., T. Khanna. (2000). Do firms learn to create value? The case of alliances. Strategic Management Journal, 21(3) 295-315.

Arino, A., \& de la Torre, J. 1998. Learning from failure: Towards an evolutionary model of collaborative ventures. Organization Science, 9(3): 306-326.

Argote, L. 1999. Organizational learning: Creating, retaining, and transferring knowledge. Hingham, MA: Kluwer Academic Publishing.

Balakrishnan S, Koza MP. 1993. Information asymmetry, adverse selection and joint ventures: theory and evidence. Journal of Economic Behavior and Organization 20: 99-117.

Barkema HG, Shenkar O, Vermeulen F, Bell JHJ. 1997. Working abroad, working with others: how firms learn to operate international joint ventures. Academy of Management Journal 40(2): 426-442.

Barnett, W. P., Greve, H. R., Park, D. Y. 1994. An evolutionary model of organizational performance. Strategic Management Journal, 15: 11-28.

Barney, J. B., \& Hesterley, W. 1996. Organizational economics: Understanding the relationship between organizations and economic analysis. In S. R. Clegg, C. Hardy, \& W. Nord (Eds.), Handbook of Organizational Studies: 115-147. London: Sage.

Bleeke, J., Ernst, D. (1995). Is your strategic alliance really a sale? Harvard Business Review, 97-105.

Bransford, J. D., J. J. Franks. 1976. Toward a framework for understanding learning. G. H. Bower, ed. The Psychology of Learning and Motivation, Vol. 10. Academic Press, New York, 93-127.

Cheng, P. W., K. J. Holyoak, R. E. Nisbett, L. M. Oliver. 1986. Pragmatic versus syntactic approaches to training deductive reasoning. Cognitive Psych. 18(3) $293-$ 328.

Cohen WM, Levinthal DA. 1990. Absorptive capacity: a new perspective on learning and innovation. Administrative Science Quarterly 35(1): 128-152. 
Cyert, R., J. March. 1963. A Behavioral Theory of the Firm, 2nd ed. Prentice-Hall, Englewood Cliffs, NJ.

Dosi, G., R. R. Nelson and S. G. Winter (2000), 'Introduction: The Nature and Dynamics of Organisational Capabilities,' in G. Dosi, R. R. Nelson, and S. G. Winter (eds), The Nature and Dynamics of Organisational Capabilities. Oxford University Press: Oxford, pp. 1-22.

Doz, Y., \& Hamel, G. 1998. Alliance advantage: The art of creating value through partnering. Boston, MA: Harvard Business School Press.

Dikova, D., Sahib, P.R., Witteloostuijn, A.V. (2010). Cross-border acquisition abandonment and completion: The effect of institutional differences and organizational learning in the international business service industry,1981-2001. Journal of International Business Studies, 41, 223-245

Dyer JH, Singh H. 1998. The relational view: cooperative strategy and sources of interorganizational competitive advantage. Academy of Management Review 23:660-679.

Ghemawat, P. 2001. Distance still matters: The hard reality of global expansion. Harvard Business Review, 79(8): 137-147.

Gick, M. L., K. J. Holyoak. 1983. Schema induction and analogical transfer. Cognitive Psych. 15(1) 1-38.

Gick, M. L., K. J. Holyoak. 1987. The cognitive basis of knowledge transfer. S. M. Cormier, J. D. Hagman, eds. Transfer of Learning: Contemporary Research and Applications. Academic Press, New York.

Goerzen A, Beamish PW. 2005. The effect of alliance network diversity on multinational enterprise performance. Strategic Management Journal 26(4):333-354.

Gulati, R., D. Lavie, H. Singh. 2009. The nature of partnering experience and the gains from alliances. Strategic Management J.30(11) 1213-1233.

Hagedoorn J, Sadowski B. 1999. Transition from strategic technology alliances. Journal of Management Studies 36(1): 87-107.

Haleblian J, Finkelstein S. (1999). The influence of organizational acquisition experience on acquisition performance: a behavioral learning perspective. Administrative Science Quarterly, 44(1): 29-56.

Haleblian, J., Kim, J., and Rajagopalan, N. (2006). The influence of acquisition experience and performance on acquisition behavior: Evidence from the U.S. commercial banking industry. Academy of Management Journal, 49: 357-370. 
Haspeslagh, P., D. Jemison. 1991. Managing Acquisitions: Creating Value Through Corporate Renewal. Free Press, New York.

Hayes, J. R., H. A. Simon. 1977. Psychological differences among problem isomorphs. N. J. Castellan Jr., D. B. Pisoni, G. Potts, eds. Cognitive Theory. Lawrence Erlbaum Associates, Hillsdale, NJ, 21-44.

Hayward M.L.A. (2002). When do firms learn from their acquisition experience? Evidence from 1990-1995. Strategic Management Journal, 23(1): 21-39.

Higgins MJ, Rodriguez D. 2006. The outsourcing of R\&D through acquisitions in the pharmaceutical industry. Journal of Financial Economics, 80(2): 351-383.

Holland, J. H., K. J. Holyoak, R. E. Nisbett, P. R. Thagard. 1986. Induction: Processes of Inference, Learning, and Discovery. MIT Press, Cambridge, MA.

Holyoak, K. J. 1985. The pragmatics of analogical transfer. G. H. Bower, ed. The Psychology of Learning and Motivation, Vol. 19. Academic Press, New York, 59-87.

Huber, G. P. 1991. Organizational learning: The contributing processes and literatures. Organization Science, 2: 88-115.

Ingram, P., J. A. C. Baum. 1997. Opportunity and constraint: Organizations' learning from the operating and competitive experience of industries. Strategic Management Journal, 18(S1) 75-98.

Ingram, P., Simons, T. 2002. The transfer of experience in groups of organizations: Implications for performance and competition. Management Science; Dec 2002; 48, 12; pg. 1517

Inkpen, A. C., S. C. Currall. 2004. The coevolution of trust, control, and learning in joint ventures. Organization Science. 15(5) 586-599.

Jiang, R.J., Tao, Q.T, Santoro, M.D. 2010. Alliance portfolio diversity and firm performance. Strategic Management Journal, 31: 1136-1144

Laamanen T, Keil T. 2008. Performance of serial acquirers: toward an acquisition program perspective. Strategic Management Journal 29(6): 663-672.

Lane P.J. and Lubatkin M.H.. (1998). Relative absorptive capacity and interorganizational learning. Strategic Management Journal 19(5): 461-477.

Larkin, J., J. McDermott, D. Simon, H. A. Simon. 1980. Expert and novice performance in solving physics problems. Science 208(4450) 1335-1342.

March, J. G., D. A. Levinthal. 1993. The myopia of learning. Strategic Management Journal. 14 95-112.

March J.G., Simon H. 1958. Organizations. Wiley: New York. 
March, J. G. 1981. Footnotes to organizational change. Administrative Science Quarterly, 26: $563-577$.

McNamara, G.M., Haleblian, J.J., and Dykes, B.J. (2008). The Performance Implications of Participating in an Acquisition Wave: Early Mover Advantages, Bandwagon Effects, and the Moderating Influence of Industry Characteristics and Acquirer Tactics. Academy of Management Journal, 51, No. 1, 113-130.

Meeks, G., \& Meeks, J. G. (1981). Profitability measures as indicators of post-merger efficiency. The Journal of Industrial Economics, 29(4), 335-335.

Moorman, C., and Miner, A. S. (1998). Organizational improvisation and organizational memory. Academy of Management Review, 23(4), 698-723.

Nelson, R. R., \& Winter, S. G. (1982). An evolutionary theory of economic change. Cambridge, MA: Harvard University Press.

Phene, A., Tallman, S. 2012. Complexity, context and governance in biotechnology alliances. Journal of International Business Studies. 43, 61-83

Pisano GP. 1994. Knowledge, integration and the locus of learning: an empirical analysis of process development. Strategic Management Journal, Winter Special Issue 15: $85-100$.

Porrini, P. (2004). Can a previous alliance between an acquirer and a target affect acquisition performance? Journal of Management, 30(4), 545-562.

Reed, S. K., G. W. Erst, R. Banerji. 1974. The role of analogy in transfer between similar problem states. Cognitive Psych. 6(3) 436-450.

Reich RB, Mankin ED. 1986. Joint ventures with Japan give away our future. Harvard Business Review 64:78-86.

Reuer JJ, Ragozzino R. 2006. Agency hazards and alliance portfolios. Strategic Management Journal 27(1): 27-43.

Reuer, J. J., Zollo, M., \& Singh, H. (2002). Post-formation dynamics in strategic alliances. Strategic Management Journal,23(2), 135-151.

Robson, M. J., C. S. Katsikeas, D. C. Bello. 2008. Drivers and performance outcomes of trust in international strategic alliances: The role of organizational complexity. Organization Science. 19(4) 647-665.

Schilling, M. A. 2009. Understanding the alliance data. Strategic Management Journal, 30(03): 230-260. 
Stuart T E. 2000. Interorganizational alliances and the performance of firms: a study of growth and innovation rates in a high-technology industry. Strategic Management Journal 21(8): 791-811.

Teece DJ, Pisano G, Shuen A. 1997. Dynamic capabilities and strategic management. Strategic Management Journal 18(7): 509-533.

Thorndike E L, Woodworth R S 1901 The influence of improvement in one mental function upon the efficiency of other functions. Psychological Review 8: 247-261

Thorndike, E. L. 1903. Educational Psychology. Lemcke and Buechner, New York.

Tversky, A. 1977. Features of similarity. Psych. Review. 84(4) 327-352.

Verbeke, A. (2010). International acquisition success: Social community and dominant logic dimensions. Journal of International Business Studies, 41(1), 38.

Vermeulen, F., \& Barkema, H. (2001). Learning through acquistions. Academy of Management Journal, 44(3), 457.

Wegner, D. M. 1986. Transactive memory: A contemporary analysis of the group mind. In B. Mullen \& G. R. Goethals (Eds.), Theories of Group Behavior: 185-208. New York: Springer-Verlag.

Wang, L., \& Zajac, E. J. (2007). Alliance or acquisition? A dyadic perspective on interfirm resource combinations. Strategic Management Journal, 28(13), 1291.

Winter, S. G. (2000), The satisficing principle in capability learning. Strategic Management Journal, 21, 981-996

Winter, S. G. (2003), Understanding dynamic capabilities. Strategic Management Journal, 24, 991-995.

Zaheer, S. 1995. Overcoming the liability of foreignness. Academy of Management Journal. 38(2) 41-63.

Zaheer, A., Hernandez, E., Banerjee, S. 2010. Prior Alliances with Targets and Acquisition Performance in Knowledge-Intensive Industries. Organization Science 21(5) 1072-1091.

Zaheer A, McEvily B, Perrone V. 1998. Does trust matter? Exploring the effects of interorganizational and interpersonal trust on performance. Organization Science. 9(2): 141-159.

Zander, U., Zander, L. 2010. Opening the grey box: Social communities, culture and knowledge in acquisitions. Journal of International Business Studies, 41(1): $27-$ 37. 
Zeira, Y., \& Newburry, W. 1999. Equity international joint ventures (EIJVs) and international acquisitions (IAs): Generic differences in the pre- and postincorporation stages. Management International Review, 39(4), 323-352.

Zollo, M., \& Reuer, J. J. 2010. Experience spillovers across corporate development activities. Organization Science, 21(6), 1195-1212,1275-1276.

Zollo, M., Reuer, J. J., \& Singh, H. (2002). Interorganizational routines and performance in strategic alliances. Organization Science, 13(6), 701-713.

Zollo, M., S. G. Winter. 2002. Deliberate learning and the evolution of dynamic capabilities. Organization Science. 13(3) 339-351. 
FIGURE 1: OVERARCHING FRAMEWORK OF THE DISSERTATION

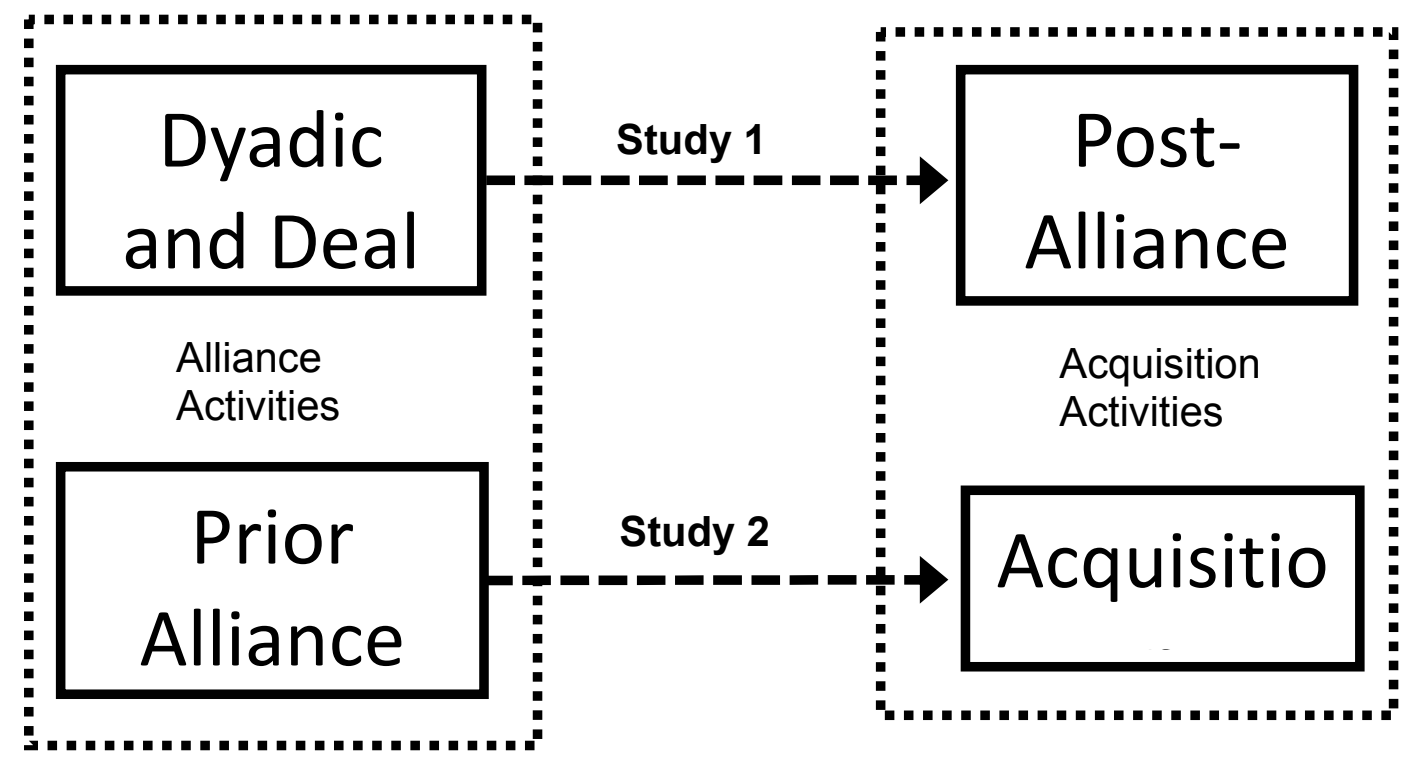

FIGURE 2 - STUDY I: CONCEPTUAL MODEL OF THE STUDY

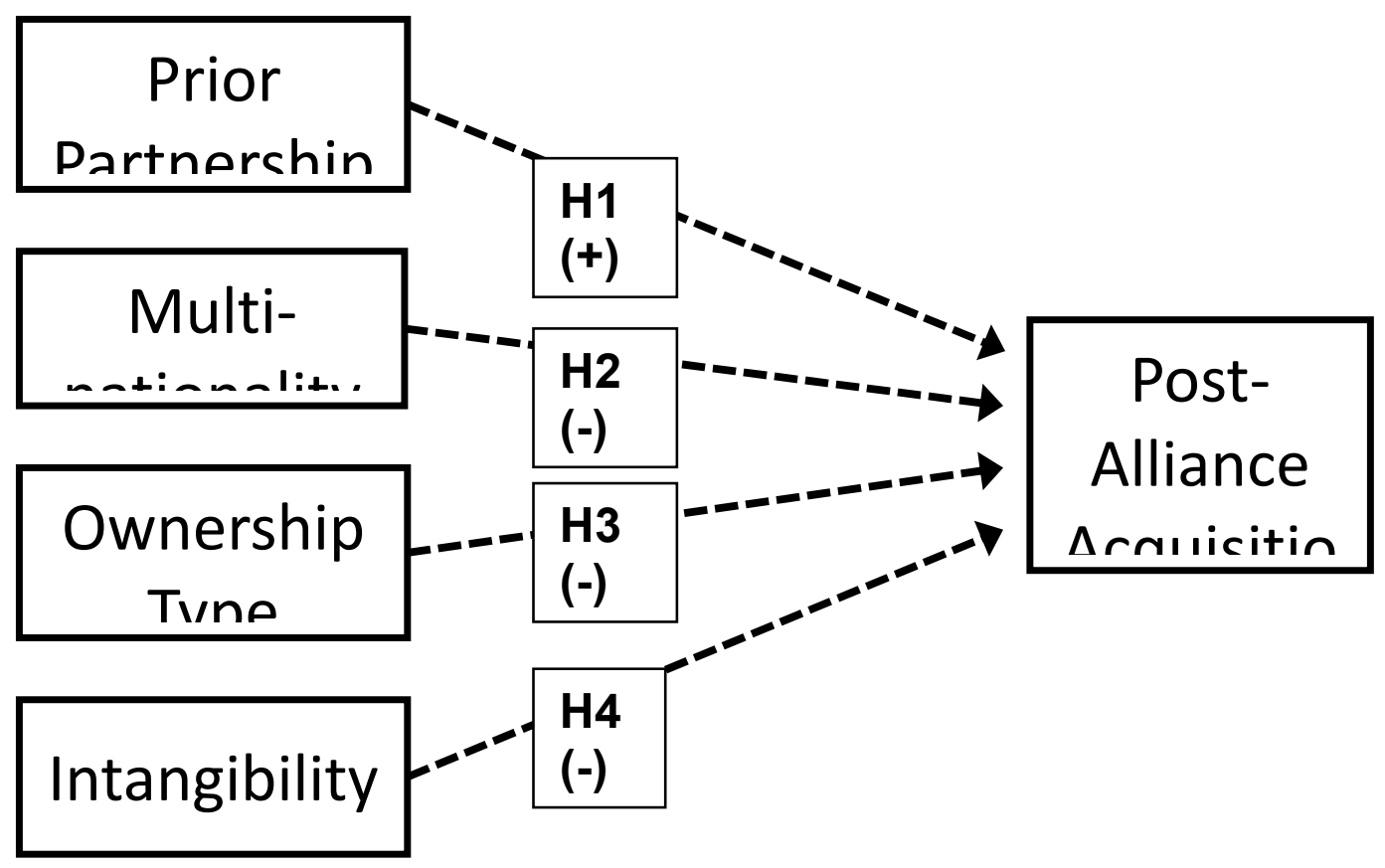




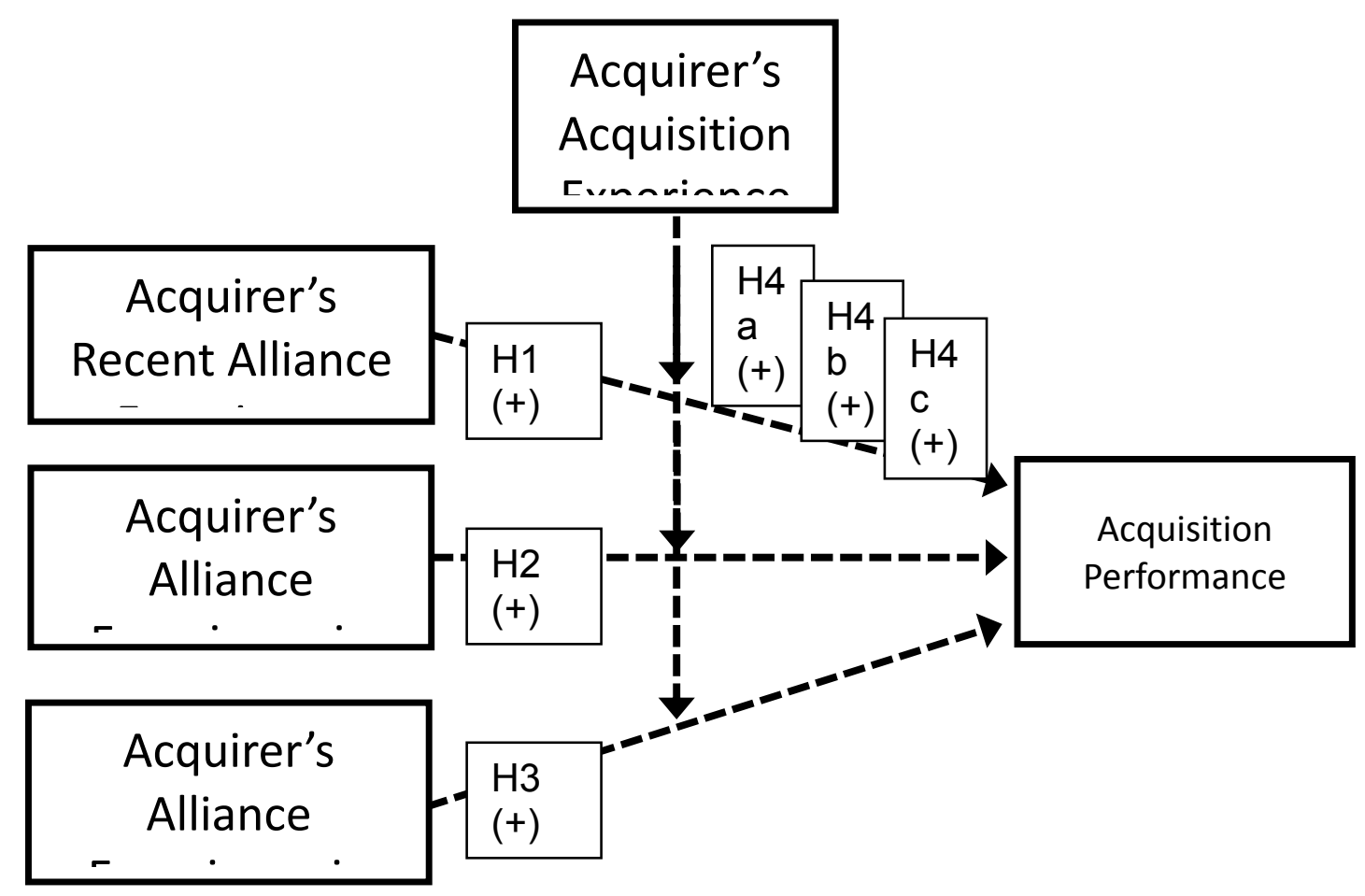


TABLE 1 - STUDY I: CORRELATIONS ESTIMATES FROM LOGISTIC REGRESSION

\begin{tabular}{|c|c|c|c|c|c|c|c|c|c|c|}
\hline Variables & [1] & [2] & [3] & [4] & [5] & [6] & [7] & [8] & [9] & {$[10]$} \\
\hline [1] Acquisition Attempt & 1 & & & & & & & & & \\
\hline [2] Prior partnership & -0.0791 & 1 & & & & & & & & \\
\hline [3] Multi-nationality & 0.2107 & -0.0132 & 1 & & & & & & & \\
\hline $\begin{array}{l}\text { [4] Organizational Type } \\
\text { Difference }\end{array}$ & -0.0595 & 0.0645 & -0.0519 & 1 & & & & & & \\
\hline [5] Intangibility & -0.1787 & 0.0292 & -0.0414 & 0.0792 & 1 & & & & & \\
\hline $\begin{array}{l}\text { [6] Prior acquisition } \\
\text { experience }\end{array}$ & 0.0457 & -0.0079 & 0.0468 & -0.0146 & -0.0098 & 1 & & & & \\
\hline [7] Prior alliance experience & -0.0303 & 0.1409 & 0.0101 & 0.0554 & 0.062 & 0.256 & 1 & & & \\
\hline $\begin{array}{l}\text { [8] Number of alliance } \\
\text { partners }\end{array}$ & -0.1986 & 0.0337 & -0.1033 & -0.1219 & -0.0432 & -0.044 & -0.0456 & 1 & & \\
\hline [9] Target attractiveness & 0.0461 & -0.0056 & 0.0483 & -0.0135 & -0.0087 & 0.9989 & 0.275 & -0.0456 & 1 & \\
\hline $\begin{array}{l}\text { [10] Acquirer's Public } \\
\text { Status }\end{array}$ & -0.0282 & 0.0466 & -0.0096 & -0.0356 & 0.1734 & -0.027 & 0.0987 & -0.0654 & -0.0265 & 1 \\
\hline
\end{tabular}


TABLE 2 - STUDY I: DESCRIPTIVE STATISTICS

\begin{tabular}{lcr}
\hline Variables & Mean & Std. Dev. \\
\hline Prior partnership & 0.009 & 0.097 \\
Multi-nationality & 0.591 & 0.491 \\
Ownership type difference & 0.512 & 0.499 \\
Intangibility & 0.909 & 0.287 \\
Prior acquisition experience & 4.184 & 29.3 \\
Prior alliance experience & 6.308 & 18.640 \\
Number of alliance partners & 8.406 & 23.192 \\
Target attractiveness & 4.095 & 10.475 \\
Acquirer's public status & 7.543 & 21.583 \\
\hline
\end{tabular}


TABLE 3 - STUDY I: ESTIMATES FROM LOGISTIC REGRESSIONS

\begin{tabular}{|c|c|c|c|c|c|}
\hline Variables & $\begin{array}{l}\text { (I) } \\
\text { Model } 1 \\
\end{array}$ & $\begin{array}{l}\text { (II) } \\
\text { Model } 2 \\
\end{array}$ & $\begin{array}{l}\text { (III) } \\
\text { Model } 3 \\
\end{array}$ & $\begin{array}{l}(\mathrm{IV}) \\
\text { Model } 4 \\
\end{array}$ & $\begin{array}{l}\text { (V) } \\
\text { Model } 5 \\
\end{array}$ \\
\hline \multirow[t]{2}{*}{ CV1 Prior alliance experience } & $-0.00872 * *$ & $-0.00972 * * *$ & $-0.00929 * *$ & $-0.00870 * * *$ & $-0.00741 * * *$ \\
\hline & $(0.000517)$ & $(0.000514)$ & $(0.000514)$ & $(0.000512)$ & $(0.000522)$ \\
\hline \multirow{2}{*}{ CV2 Number of alliance partners } & $-1.173 * *$ & $-1.206 * * *$ & $-1.294 * * *$ & $-1.252 * *$ & $-1.183 * * *$ \\
\hline & $(0.0326)$ & $(0.0326)$ & $(0.0331)$ & $(0.0326)$ & $(0.0337)$ \\
\hline \multirow[t]{2}{*}{ CV3 Acquirer's Public Status } & $-0.289 * *$ & $-0.304 * * *$ & $-0.233 * * *$ & $-0.214 * *$ & $-0.103 * * *$ \\
\hline & $(0.0249)$ & $(0.0249)$ & $(0.0252)$ & $(0.0254)$ & $(0.0262)$ \\
\hline \multirow[t]{2}{*}{ CV4 Prior acquisition experience } & $-2.91 \mathrm{e}-05^{* *}$ & $-2.94 \mathrm{e}-05^{* * *}$ & $-2.95 \mathrm{e}-05^{* *}$ & $-2.82 \mathrm{e}-05^{* * *}$ & $-2.23 \mathrm{e}-05 * * *$ \\
\hline & $(3.12 \mathrm{e}-06)$ & $(3.09 \mathrm{e}-06)$ & $(3.13 \mathrm{e}-06)$ & $(3.07 \mathrm{e}-06)$ & $(2.97 \mathrm{e}-06)$ \\
\hline \multirow[t]{2}{*}{ CV5 Target attractiveness } & $0.00869 * *$ & $0.00878 * * *$ & $0.00881 * *$ & $0.00843 * * *$ & $0.00665 * * *$ \\
\hline & $(0.000908)$ & $(0.000901)$ & $(0.000911)$ & $(0.000895)$ & $(0.000862)$ \\
\hline \multirow[t]{2}{*}{ H1 Prior partnership } & $-3.369 * *$ & & & & $-3.238 * * *$ \\
\hline & $(0.271)$ & & & & $(0.272)$ \\
\hline H2 Multi-nationality & & $-0.470 * * *$ & & & $-0.680 * * *$ \\
\hline
\end{tabular}


H3 Ownership Type Difference

\begin{tabular}{|c|c|c|c|c|c|}
\hline \multirow[t]{2}{*}{ H3 Ownership Type Difference } & & \multicolumn{3}{|c|}{$-0.419 * *$} & \multirow{2}{*}{$\begin{array}{l}-0.308 * * * \\
(0.0217)\end{array}$} \\
\hline & & & $(0.0210)$ & & \\
\hline \multirow[t]{2}{*}{ H4 Intangibility } & & & & $-1.113^{* *}$ & $-1.045^{* * *}$ \\
\hline & & & & $(0.0453)$ & $(0.0466)$ \\
\hline \multirow[t]{2}{*}{ Constant } & $1.785 * *$ & $1.847 * * *$ & $2.089 * *$ & $2.838 * *$ & $1.637 * * *$ \\
\hline & $(0.0698)$ & $(0.0700)$ & $(0.0716)$ & $(0.0820)$ & $(0.0621)$ \\
\hline Observations & 43,469 & 43,469 & 43,469 & 43,469 & 43,469 \\
\hline chi-square & 4664 & 4171 & 4571 & 4825 & 4583 \\
\hline
\end{tabular}

H4 Intangibility

Robust standard errors are shown in parentheses. Year binary variables included.

Note: $\mathrm{N}=43,469 .\left(^{*}\right)$ Indicates a significance level of less than $0.05 ;\left(\left(^{* *}\right)\right.$ less than $0.01 ;\left(^{* * *}\right)$ less than 0.001 
TABLE 1 - STUDY II: CORRELATIONS ESTIMATES

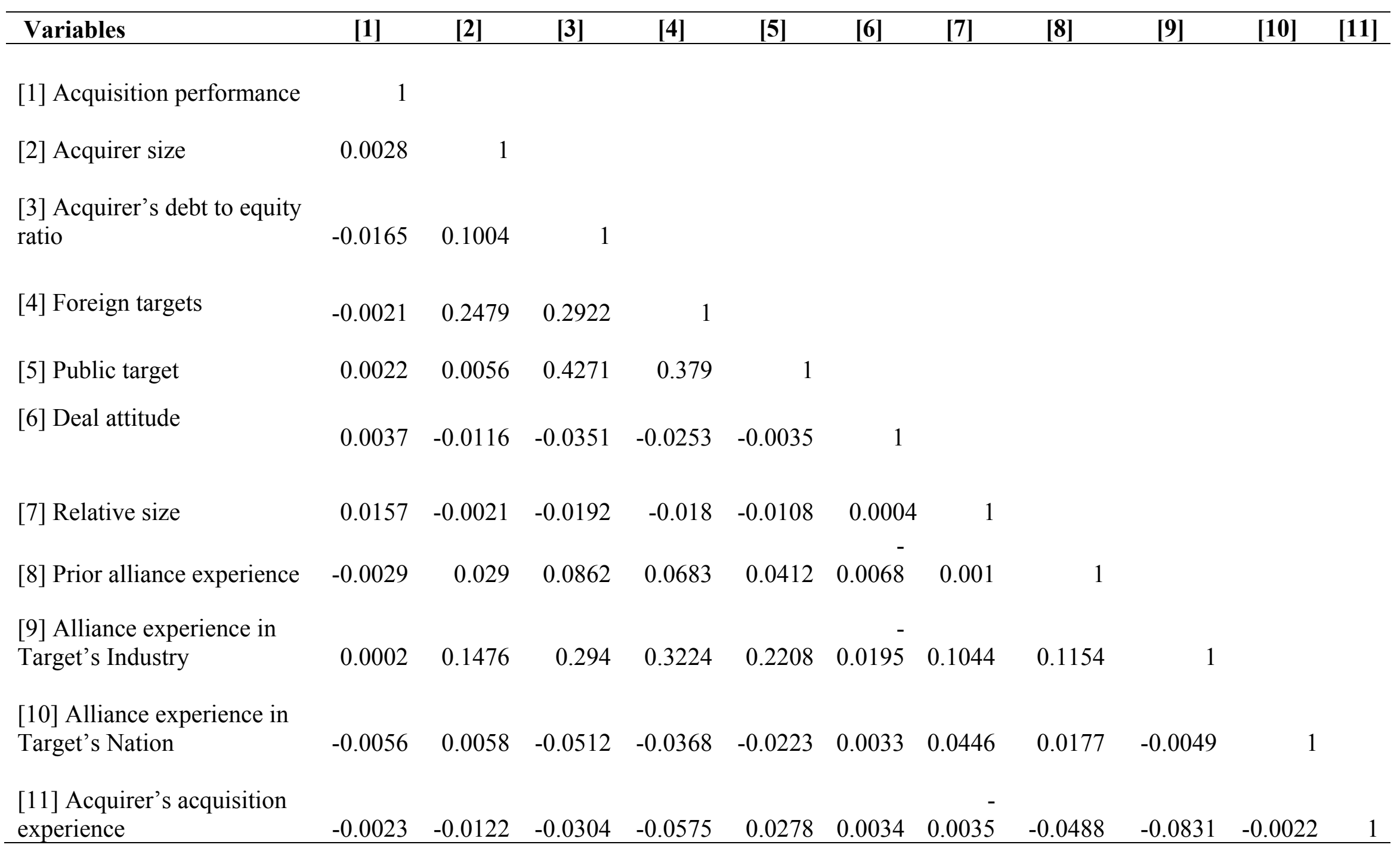


TABLE 2 - STUDY II: DESCRIPTIVE STATISTICS

\begin{tabular}{lrr}
\hline Variables & Mean & Std. Dev. \\
\hline Acquisition performance & -0.133 & 189.860 \\
Acquirer size & 6.835 & 2.289 \\
Acquirer's debt to equity ratio & 2.443 & 13.188 \\
Foreign targets & 0.175 & 0.380 \\
Public target & 0.127 & 0.333 \\
Deal attitude & 0.946 & 0.226 \\
Relative size & 0.386 & 3.839 \\
Prior alliance experience & 8.406 & 23.192 \\
Alliance experience in Target's & 4.095 & 10.475 \\
Industry & & \\
Alliance experience in Target's & 7.543 & 21.583 \\
Nation & & \\
Acquirer's acquisition experience & 9.609 & 20.409 \\
\hline
\end{tabular}


TABLE 3 - STUDY II: ESTIMATES FROM ORDINARY LEAST SQUARES REGRESSION ANALYSES

\begin{tabular}{|c|c|c|c|c|c|}
\hline Variables & $\begin{array}{c}\text { (I) } \\
\text { Model 1 }\end{array}$ & $\begin{array}{c}\text { (II) } \\
\text { Model } 2\end{array}$ & $\begin{array}{c}\text { (III) } \\
\text { Model } 3\end{array}$ & $\begin{array}{c}(\text { IV) } \\
\text { Model } 4\end{array}$ & $\begin{array}{c}(\mathrm{V}) \\
\text { Model } 5\end{array}$ \\
\hline \multirow[t]{2}{*}{ CV1 Acquirer size } & 0.0801 & $-5.442 *$ & $-5.419 *$ & $-5.364^{*}$ & $-5.361 *$ \\
\hline & $(0.141)$ & $(2.931)$ & $(2.940)$ & $(2.949)$ & $(2.967)$ \\
\hline \multirow{2}{*}{$\begin{array}{l}\text { CV2 Acquirer's debt to equity } \\
\text { ratio }\end{array}$} & $5.871 * * *$ & $24.22 * *$ & $24.51 * *$ & $24.41 * *$ & $24.43 * *$ \\
\hline & $(1.721)$ & $(10.90)$ & $(10.94)$ & $(10.97)$ & $(11.08)$ \\
\hline \multirow[t]{2}{*}{ CV3 Foreign targets } & $14.72 *$ & 50.95 & 47.79 & 50.68 & 50.77 \\
\hline & $(8.001)$ & $(71.61)$ & $(72.08)$ & $(72.38)$ & $(72.97)$ \\
\hline \multirow[t]{2}{*}{ CV4 Public target } & -0.503 & -13.01 & -12.61 & -12.80 & -12.81 \\
\hline & $(3.597)$ & $(17.62)$ & $(17.69)$ & $(17.74)$ & $(17.84)$ \\
\hline \multirow[t]{2}{*}{ CV5 Deal attitude } & 0.0108 & -0.625 & -1.758 & -5.635 & -5.634 \\
\hline & $(0.243)$ & (11.03) & $(11.27)$ & $(12.69)$ & $(12.74)$ \\
\hline \multirow[t]{3}{*}{ CV6 Relative size } & -1.341 & $61.39 *$ & $64.29^{*}$ & $61.48 *$ & 61.79 \\
\hline & $(2.672)$ & $(34.42)$ & $(34.95)$ & $(35.29)$ & $(41.52)$ \\
\hline & 3.703 & -4.640 & -4.408 & -4.650 & -4.647 \\
\hline
\end{tabular}


H1 Acquirer's alliance experience (AALE)

$\mathrm{H} 2$ Alliance experience in target's Industry (AETI)

H3 Alliance experience in target's nation (AETN)

H4 Acquirer's acquisition experience (AACE)

H4a AALE*AACE

H4b AETI*AACE

H4c AETN*AACE

$\begin{array}{cccc}-5.442 * & -5.419 * & -5.364 * & -5.361^{*} \\ -0.243 & -0.296 & -0.291 & -0.291 \\ (0.174) & (0.201) & (0.202) & (0.203) \\ 9.215 & 8.542 & 12.94 & 12.95 \\ (11.47) & (11.57) & (13.31) & (13.42) \\ 61.09 * * * & 62.42 * * * & 59.83 * * & 59.74 * * \\ (23.11) & (23.32) & (23.69) & (24.53) \\ 0.116 & -0.0187 & 0.123 & 0.104 \\ (0.201) & (0.324) & (0.387) & (1.376) \\ & & & (0.239) \\ & 0.00128 & 0.00122 & 0.00122 \\ & (0.00242) & (0.00242) & (0.00244) \\ & & -0.160 & -0.160 \\ & & (0.238) & (0.0197\end{array}$




\begin{tabular}{lccccc} 
Constant & $-43.92 * * *$ & $-213.3^{* *}$ & $-212.3^{* *}$ & $-213.0^{* *}$ & $-213.1^{* *}$ \\
& $(12.90)$ & $(77.47)$ & $(78.76)$ & $(79.84)$ & $(80.24)$ \\
Observations & & & & 314 & 314 \\
R-squared & 5,396 & 314 & 0.297 & 0.300 & 0.300 \\
\hline
\end{tabular}

Robust standard errors are shown in parentheses. Year variables included. Year and industry binary variables included. Note: $\mathrm{N}=5,396 .\left(^{*}\right)$ Indicates a significance level of less than $0.1 ;\left(^{* *}\right)$ less than $0.05 ;\left(^{* * *}\right)$ less than 0.01 


\section{RIMI ZAKARIA}

Born: Dhaka, Bangladesh

1998-2003 Bachelor of Social Sciences with Honors (BSS) in International Relations University of Dhaka (DU), Dhaka, Bangladesh

2005-2007 Master of Business Administration (MBA)

Graduate Assistant

College of Business, University of Central Arkansas (UCA), Conway, Arkansas

2007-2008 Adjunct Professor

Dept. of Economics, Finance, and Insurance \& Risk Management (EFIRM)

College of Business, University of Central Arkansas (UCA), Conway, Arkansas

2007-2008 Management Consultant

The RockTenn Company (NYSE: RKT)

Conway Division, Arkansas

2008-2013 Doctor of Philosophy in Business Administration (PhD)

Specialization: Strategic and International Management

Instructor \& Graduate Assistant at Management and International Business Dept.

Florida International University (FIU), Miami, Florida

2012-To Date Assistant Professor of Management

College of Business and Economics

University of Wisconsin - Whitewater (UWW), Whitewater, Wisconsin

\section{NOTABLE PRESENTATIONS}

Zakaria, R. and Kundu, S. K. (October, 2009) Institutional Environment, Firm Motives, Entry Strategy: When Certainty Is a Source of Uncertainty. Presented at the Strategic Management Society (SMS) Conference, Washington, DC

Zakaria, R. and Tanyi, P. N. (June, 2010) Relationship between Internationalization and Top Executive's Job Prospect: Tacit Knowledge Perspective. Presented at the Academy of International Business (AIB) Conference, Rio de Janeiro, Brazil

Zakaria, R. (August, 2010) Knowledge-Based Theory: Corporate Executive Mobility and Individual-level Rent Appropriation. Presented at the Academy of Management (AOM) Conference, Montreal, Canada

Zakaria, R. and Kundu, S.K. (April, 2011) Relative Importance of Formal vs. Informal Institutions in the Context of Strategic Alliance Performance. Presented at the Third Reading International Business (AIB) Conference, Reading, United Kingdom

Zakaria, R. (May, 2011) Relationship between Supranational Institutions and Cross-border Acquisitions: A Nation-state Network View. Presented at the Consortium on Multidisciplinary Approaches to Regional Economic Integration: Competition \& Cooperation in the EU, Johns Hopkins University, Washington, DC 
Zakaria, R. (June, 2011) Typological Conceptualization of Distance: A Quest of Relative Importance. Presented at the Academy of International Business (AIB) Conference, Nagoya, Japan

Zakaria, R., Thams, Y., and Kelley, K. J. (August, 2011) Relational Typology of Institutional Distance and M\&A Transactions: A Two-Dimensional View. Presented at the Academy of Management (AOM) Conference, San Antonio, TX

Zakaria, R., Douglas-Fernandez, W., Schneper, W. (June, 2012) Environmental Munificence, Prior Experience, and the Prevalence of Cross-Border Mergers \& Acquisitions. Presented at the Academy of International Business (AIB) Conference, Washington, DC

Zakaria, R. (August, 2012) Implications of Knowledge and Learning for Alliance Performance and Post-alliance Strategy. Presented at the Academy of Management (AOM) Conference, Boston, MA

\section{SCHOLARSHIPS AND AWARDS}

1998-2003 National Merit Scholarship by Bangladesh Government to pursue Bachelor's at DU

University of Dhaka Sports Scholarship for extraordinary achievements in intraand inter-university indoor sports

MBA scholarship at UCA in terms of full tuition waiver and graduate assistantship Outstanding International Student Scholarship to pursue MBA at UCA

2005-2007 MBA Textbook Scholarship at UCA funded by the Dean of College of Business

2006-2007 Privately funded MBA scholarship awarded by UCA Alumni Association Doctoral funding at FIU

2008-2013 Conference travel awards from the Dean, Management and International Business (MIB) Department, Graduate Student Funding Committee (GSFC), and CIBER at FIU

2011 The Penn Lauder/FIU CIBER Award to attend the Faculty Development Program at the Wharton School, University of Pennsylvania

2011 Women in the Academy of International Business (WAIB) Helping Hands Award 2011 Faculty Research Awards from FIU CIBER

2012 Women in the Academy of International Business (WAIB) Helping Hands Award 2012 Academy of International Business (AIB) Doctoral Stipend

2012-13 University of Wisconsin - Madison, Library Research Fellowship 